\title{
THE FIRST SOCIAL \& ENVIRONMENTAL REPORT OF THE EUROPEAN LEATHER INDUSTRY
}

\author{
PRIMUL RAPORT SOCIAL ŞI DE MEDIU AL INDUSTRIEI EUROPENE DE PIELĂRIE
}

\author{
Federico BRUGNOLI ${ }^{1}$, Gustavo GONZALEZ-QUIJANO ${ }^{1}$, Luminita ALBU ${ }^{2 *}$
}

${ }^{1}$ COTANCE, 3 Rue Belliard, B-1040 Brussels, Belgium, email: brugnoli@spin360.biz, cotance@euroleather.com

${ }^{2}$ INCDTP - Division: Leather and Footwear Research Institute, 93 Ion Minulescu, 031215, Bucharest, Romania, email: luminita.albu@icpi.ro

\section{THE FIRST SOCIAL \& ENVIRONMENTAL REPORT OF THE EUROPEAN LEATHER INDUSTRY}

ABSTRACT. This first Social \& Environmental Report of the European Leather Industry has been elaborated within the context of the SER III Social Dialogue Project, implemented by the social partners of the European Tanning Industry: COTANCE and IndustriAll-European Trade Union. The paper represents a novel approach which takes into consideration the main elements that are linked with the sustainable development and economic growth of European tanneries. Key strategic concepts illustrated in the paper concern the ecological role of tanneries that base their production on by-products of renewable origin. They build their leadership on a mix of tradition and innovation and therefore require a particularly skilled workforce. The paper, moreover, presents in detail the structure of the European sector and, thanks to the contribution of several national industrial associations (representing $90.9 \%$ of European tanneries and $76.6 \%$ of the workforce), provides key environmental and social indicators linked with the industrial activity. The comprehensive analysis of social and environmental indicators demonstrates that tanneries in Europe are increasingly committed to the ethical and social aspects of their business, and that, through continuous investments, they have been able to ensure substantial improvements in process efficiency and in pollution prevention and control. All the efforts made by European tanneries over the years have resulted in improving the sustainability of their production. The excellent results achieved deserve to be valued more by stakeholders and better incentivised through measures encouraging new and future investments. The environmental and social values demonstrated by European leather help to keep European tanners ahead of international competition.

KEYWORDS: social report, ecological role, sustainable development, leadership, tradition \& innovation

\section{PRIMUL RAPORT SOCIAL ŞI DE MEDIU AL INDUSTRIEI EUROPENE DE PIELĂRIE}

REZUMAT. Acest prim Raport Social şi de Mediu al Industriei Europene de Pielărie a fost elaborat în cadrul proiectului de Dialog Social SER III, implementat de partenerii sociali ai industriei europene de pielărie: COTANCE şi Federaţia sindicală europeană IndustriAll. Această lucrare reprezintă o nouă abordare care ia în considerare principalele elemente asociate cu dezvoltarea durabilă a tăbăcăriilor europene. Conceptele-cheie strategice prezentate în această lucrare privesc rolul ecologic al tăbăcăriilor a căror producție se bazează pe produse secundare regenerabile. Spiritul de conducere al acestora se bazează pe combinarea tradiţiei cu inovarea şi, prin urmare, necesită o forţă de muncă special calificată. Mai mult decât atât, lucrarea prezintă în detaliu structura sectorului european şi, mulţumită contribuţiei mai multor asociaţii naţionale (reprezentând $90,9 \%$ din tăbăcăriile europene şi $76,6 \%$ din forţa de muncă), oferă indicatori-cheie sociali şi de mediu asociaţi cu activitatea industrială. Analiza cuprinzătoare a indicatorilor sociali şi de mediu demonstrează că tăbăcarii din Europa sunt din ce în ce mai angajaţi în aspectele etice şi sociale ale afacerii lor şi că, prin investiţii continue, au fost capabili să asigure îmbunătăţiri substanţiale în eficienţa proceselor şi în prevenirea şi controlul poluării. Toate eforturile depuse de tăbăcăriile europene de-a lungul anilor au avut ca urmare îmbunătăţirea sustenabilităţii producţiei acestora. Rezultatele excelente obţinute merită să fie apreciate mai mult de către părţile interesate şi să fie mai bine stimulate prin măsuri care să încurajeze noi investiţii. Valorile sociale şi de mediu demonstrate de pielea europeană contribuie la menţinerea tăbăcarilor europeni în fruntea competiţiei internaţionale.

CUVINTE CHEIE: raport social, rol ecologic, dezvoltare sustenabilă, spirit de conducere, tradiţie şi inovare

\section{LE PREMIER RAPPORT SOCIAL ET ENVIRONNEMENTAL DE L'INDUSTRIE EUROPÉENNE DU CUIR}

RÉSUMÉ. Ce premier rapport social et environnemental de l'industrie européenne du cuir a été réalisé au sein du projet de Dialogue Social SER III, mis en œuvre par les partenaires sociaux de l'industrie du cuir: COTANCE et La Fédération Syndicale Européenne IndustriAll. Cet article représente une nouvelle approche qui tient compte des principaux éléments liés au développement durable des tanneries européennes. Les concepts-clés stratégiques présentés dans cet article concernent le rôle écologique des tanneries dont la production est basée sur des produits renouvelables. Leur qualité de dirigeant est basée sur la combinaison de la tradition avec l'innovation et nécessite, donc, une main d'œuvre qualifiée. En outre, l'article décrit en détail l'architecture du secteur européen et, grâce à la contribution de plusieurs associations nationales (représentant $90,9 \%$ des tanneries européennes et $76,6 \%$ de la main d'œuvre), fournit des indicateurs-clés sociaux et environnementaux liés à l'activité industrielle. Une analyse complète des indicateurs sociaux et environnementaux montre que les tanneurs européens sont de plus en plus engagés dans les aspects éthiques et sociaux de leurs activités et que, par l'investissement continu, ils ont été en mesure de fournir des améliorations substantielles dans l'efficacité des processus et dans la prévention et le contrôle de pollution. Tous les efforts des tanneurs européens au fil des ans ont permis d'améliorer la durabilité de leur production. Les excellents résultats obtenus méritent d'être plus valorisés par les parties intéressées et être mieux stimulés par des mesures visant à encourager de nouveaux investissements. Les valeurs sociales et environnementales démontrées par la peau européene contribuent à maintenir les tanneurs européens en tête de la concurrence internationale.

MOTS CLÉS: rapport social, rôle écologique, développement durable, qualité de dirigeant, tradition et innovation

* Correspondence to: Luminita ALBU, INCDTP - Division: Leather and Footwear Research Institute, 93 Ion Minulescu, 031215, Bucharest, Romania, email: luminita.albu@icpi.ro 


\section{INTRODUCTION}

The introduction describes the aim of the paper, provides a description of the social and environmental values of leather production in Europe and introductory comments on main data and indicators. This part of the report also focuses on the need of European tanners to see the international market recognising social and environmental values as drivers for a fair international trade.

The Socio-Environmental principles of EU tanning sector are enshrined in so called Framework Agreements and Joint Statements, done by COTANCE and IndustriAll, defining the Socio environmental mission of the sector, its medium term strategic objectives in terms of market, sustainability and compliance with EU strategic objectives. The section also describes the role of Social partners in the evolution of environmental and social policies of the sector.

\section{Overview of the European Leather Industry and its Socio-Environmental Values}

The tanning industry provides a high added value material to a number of value chains, notably in the fashion, furniture and automotive sectors.

The raw materials of the European tanning industry are hides and skins of which over $99 \%$ are derived from animals that have been raised primarily for wool, milk and/or meat production. This fact clearly illustrates the ecological role of tanneries; recovering a by-product, which in the absence of the leather industry would have to be disposed of, thus demonstrating similarities with the recycling industry.

European tanneries base their leadership on a mix of tradition and innovation. They keep alive a number of traditional artisan processing skills that ensure the product's high quality reputation, but invest in technological and non-technological research and development in order to remain at the forefront of product and process innovation.

Education and training, modern tanning machinery and efficient chemical auxiliaries, process automation and rationalisation, state of the art environmental protection and pioneering social responsibility all represent an integral part of the strategies of Europe's tanneries towards sustainable

\section{INTRODUCERE}

Introducerea prezintă obiectivul lucrării, oferă o descriere a valorilor sociale şi de mediu ale producţiei de piele din Europa şi comentarii introductive asupra principalelor date şi indicatori. Această parte a raportului se concentrează, de asemenea, pe nevoia tăbăcarilor europeni de a vedea că piaţa internaţională recunoaşte valorile sociale şi de mediu ca factori pentru un comerţ internaţional echitabil.

Principiile sociale şi de mediu ale sectorului de pielărie din UE sunt consfinţite în aşa-zisele acorduricadru şi declaraţii comune, încheiate de către COTANCE şi IndustriAll, care definesc misiunea socială şi de mediu a sectorului, obiectivele sale strategice pe termen mediu privind piaţa, sustenabilitatea şi conformitatea cu obiectivele strategice ale UE. Această secţiune descrie şi rolul partenerilor sociali în evoluţia politicilor sociale şi de mediu ale sectorului.

\section{Privire de ansamblu asupra industriei europene de} pielărie şi asupra valorilor sale sociale şi de mediu

Industria de pielărie oferă un material cu valoare adăugată mare unei serii de lanţuri valorice, în special în sectoarele de modă, mobilier şi automobile.

Materiile prime ale tăbăcăriilor europene sunt pieile brute din care peste $99 \%$ provin de la animale care au fost crescute în primul rând pentru lână, lapte şi/sau pentru producţia de carne. Acest fapt ilustrează în mod clar rolul ecologic al tăbăcăriilor: valorificarea unui produs secundar, care, în absenţa industriei de pielărie, ar fi eliminat, prezentând astfel asemănări cu industria de reciclare.

Spiritul de conducere al tăbăcăriilor europene se bazează pe combinarea tradiţiei cu inovarea. Ele păstrează o serie de competenţe artizanale tradiţionale de prelucrare care asigură reputaţia de înaltă calitate a produsului, investind, în acelaşi timp, în cercetare şi dezvoltare tehnologică şi non-tehnologică, pentru a rămâne în fruntea inovaţiei de produs şi de proces.

Educaţia şi formarea profesională, utilajele moderne şi auxiliarii chimici eficienţi, automatizarea şi raţionalizarea proceselor, protecţia mediului şi responsabilitatea socială de pionierat reprezintă o parte integrantă a strategiilor tăbăcăriilor din Europa spre o dezvoltare durabilă. Tăbăcăriile sunt capabile de 
development. Tanneries are capable of introducing continuously to the market new products and styles, and new applications for different end uses, but at the same time Europe's comparative advantage lies in that its tanners include in the value offer of their leathers the intangibles reflecting their response to the global challenge of sustainable development (Economical, Environmental, Social) as set out by Brundtland in 1987 (Our Common Future, WCED).

From an economic point of view, leather is a key material, generating wealth and jobs in a variety of value chains in which it is often the main constituent material, notably in shoes, clothing, leather goods, furniture, upholstery for cars, boats, aircraft, and many other items in daily use.

The environmental values of leather production have been summarised above: leather is a valuable material of renewable origin, produced through increasingly cleaner processes, consuming less energy, less water, less chemicals than in the past and reaching excellent levels of reuse and recycling of the residues produced.

Inclusivity is another key aspect of the European tanning sector that underpins the social dimension of sustainability. Workers in Europe's tanneries are more gender balanced than in other industrial sectors, and well distributed among different age groups. Some excellent examples throughout Europe show a perfect integration of different nationalities in tanneries and tanning clusters.

European tanneries are, however, at risk. Their competitiveness is in danger of disappearing in the absence of policies that foster a level playing field at international level, notably with regard to competitors in emerging economies. Competition from countries where social and environmental standards are poorly enforced causes socio-economic damage equivalent to dumping. Trade reciprocity is another element of the fair competition agenda of European tanners. Trade barriers related to access to raw materials in many third countries, such as export taxes and export restrictions on raw hides and skins, and on the intermediate material 'wet blue', severely distort prices and competition on the global leather market. a introduce pe piaţă în mod continuu produse şi stiluri noi, noi aplicaţii pentru diferite utilizări finale, dar, în acelaşi timp, avantajul comparativ al Europei constă în faptul că tăbăcarii includ în oferta lor de piei valori intangibile care reflectă răspunsul lor la provocarea globală a dezvoltării durabile (economică, de mediu, socială), aşa cum este prevăzut în raportul Brundtland din 1987 (Our Common Future, WCED).

Din punct de vedere economic, pielea este un material cheie, generând bunăstare şi locuri de muncă într-o varietate de lanţuri valorice în care este de multe ori materialul component principal, în special în domenii ca: încălţăminte, vestimentaţie, marochinărie, mobilă, tapiţerie auto, bărci, aeronave, precum şi multe alte articole de uz zilnic.

Valorile de mediu ale producţiei de piele au fost rezumate mai sus: pielea este un material valoros de origine regenerabilă, fabricată prin procese din ce în ce mai curate, care consumă mai puţină energie, mai puţină apă, mai puţine substanţe chimice decât în trecut şi care atinge niveluri excelente de refolosire şi de reciclare a reziduurilor generate.

Politica incluzivă este un alt aspect-cheie al sectorului european de pielărie, care stă la baza dimensiunii sociale a sustenabilităţii. În tăbăcăriile din Europa lucrătorii sunt mult mai bine echilibraţi din punct de vedere al genului comparativ cu alte sectoare industriale, iar distribuţia pe grupe de vârstă este mult mai echitabilă. Există exemple excelente în întreaga Europă care arată o integrare perfectă a diferitelor naţionalităţi în tăbăcării şi în clusterele de tăbăcării.

Tăbăcăriile europene sunt, totuşi, în pericol. Competitivitatea lor este în pericol de dispariţie în absenţa unor politici care să încurajeze un nivel de concurenţă echitabilă la nivel internaţional, în special cu privire la concurenţii din economiile în curs de dezvoltare. Concurenţa din ţările în care standardele sociale şi de mediu nu sunt puse în aplicare cum trebuie determină daune socio-economice echivalente cu cele ale dumping-ului. Reciprocitatea comercială este un alt element al concurenţei loiale care prezintă interes pentru tăbăcarii europeni. Barierele comerciale legate de accesul la materiile prime în multe ţări terţe, cum ar fi taxele de export şi restricţiile la export pentru pieile brute, precum şi la materialul intermediar "wet blue", denaturează grav preţurile şi concurenţa pe piaţa mondială de piei. 


\section{The European Tanning Sector}

The EU leather industry is composed of a series of different sectors, starting from the hides and skins markets, which supply the tanning industry with raw materials sourced from abattoirs dedicated to the production of meat for human consumption, and concluding with the production of manufactured consumer goods made of leather. Some of the sectors are highly industrialised, while others present a marked degree of craftsmanship and for yet others, the core business is trade and supporting services.

Strictly speaking, the leather industry refers to the tanning sector. Leather is the intermediate product of the industry, and this material represents the major input for most downstream sectors and confers their competitive advantages. EU leather is known to have the highest value added potential to the products where it is incorporated. The advantages of using leather are several: the most important are its ability to breathe, its flexibility and adaptability to a high variety of applications. Leather is produced on demand for each particular application such as footwear, clothing and gloving, leathergoods, furniture or car, yacht and airplane interiors. Tanners design the production process for conferring the specific aesthetic and performance characteristics required by the numerous end-use sectors. The present analysis (besides the tanning industry) is focused on the two traditional main destinations of leather: footwear and leather goods.

Europe has a very long tradition in the production of leather, footwear and leather goods. Consequently all these industries are present in the region and each of them also plays a relevant role on the international marketplace.

Today, under the above-mentioned considerations, the EU leather industries are composed of nearly $\mathbf{2 4 . 0 0 0}$ companies and $\mathbf{4 0 0 . 0 0 0 ~ e m p l o y e e s . ~ T h e ~ t o t a l ~}$ yearly turnover is reported to be more than $\mathbf{3 1}$ billion Euros, comprised of the following markets: $3.8 \% \mathrm{EU}$ member States' sales in their domestic market, $60.7 \%$ intra-EU trade, $35.5 \%$ extra-EU exports. The EU consequently comes out as the most prominent market by far for European leather, but the extra-EU playground is also relevant, notably with the increasingly important development of new consumer markets in emerging economies and the relocation of many customers to lower cost countries.

\section{Industria europeană de pielărie}

Industria europeană de pielărie se compune dintr-o serie de sectoare diferite, începând cu pieţele de piei brute, care aprovizionează tăbăcăriile cu materii prime provenite de la abatoarele de producţie a cărnii pentru consum, şi finalizând producţia de bunuri de consum din piele. Unele dintre sectoare sunt puternic industrializate, altele presupun un grad ridicat de meşteşug, în timp ce pentru altele, afacerea de bază o reprezintă comerţul şi serviciile suport.

Într-un sens strict, industria de pielărie se referă la sectorul de tăbăcire a pieilor. Pielea este produsul intermediar al industriei, iar acest material reprezintă contribuţia substanţială pentru majoritatea sectoarelor din aval, oferindu-le avantaje competitive. Se cunoaşte că pielea europeană are cel mai mare potenţial de valoare adăugată la produsele în care este încorporată. Avantajele utilizării pielii sunt numeroase, cele mai importante fiind proprietăţile sale igienice, flexibilitatea şi adaptabilitatea la o mare varietate de aplicaţii. Pielea este fabricată la cerere pentru fiecare tip de aplicaţie, cum ar fi încălţăminte, haine şi mănuşi, marochinărie, tapiţerie mobilă sau pentru interioare auto, iahturi şi avioane. Tăbăcarii concep procesul de producţie pentru a conferi anumite caracteristici estetice şi de performanţă specifice cerute de numeroşii utilizatori finali. Această analiză se concentrează (pe lângă industria de tăbăcire) asupra a două destinaţii principale tradiţionale ale pielii: încălţămintea şi marochinăria.

Europa are o tradiţie foarte îndelungată în producţia de piele, încălţăminte şi marochinărie. În consecinţă, toate aceste industrii sunt prezente în zonă şi fiecare joacă un rol important pe piaţa internaţională.

Având în vedere consideraţiile menţionate, industria europeană de pielărie se compune astăzi din aproximativ $\mathbf{2 4 . 0 0 0}$ de companii şi $\mathbf{4 0 0 . 0 0 0}$ de angajaţi. Cifra de afaceri anuală totală depăşeşte $\mathbf{3 1}$ de miliarde de euro, formată din următoarele pieţe: 3,8\% vânzări ale statelor membre UE pe pieţele interne (naţionale); 60,7\% comerţ intracomunitar (în interiorul UE); 35,5\% exporturi în afara UE. În consecinţă, UE devine de departe cea mai importantă piaţă pentru pielea europeană, însă şi piaţa din afara UE este relevantă, în special odată cu dezvoltarea din ce în ce mai importantă a pieţelor pentru noi consumatori în economiile în curs de dezvoltare şi cu relocarea multor clienţi în ţări cu costuri reduse. 
If we enlarge the view and consider also the other leather manufacturing segments (upholstered furniture, garments, car interiors, etc.) and the allied sectors (chemicals, machinery, etc.), the whole industry in the EU is estimated to be composed of more than 40.000 companies, employing over 500.000 people, with a total turnover of 50 billion Euro.
Dintr-o perspectivă mai largă şi luând în considerare şi celelalte segmente de producţie a pielii (tapiţerie mobilă, haine, interioare auto etc.), precum şi sectoarele conexe (substanţe chimice, utilaje etc.), întreaga industrie din UE se estimează a fi compusă din peste 40.000 companii, cu peste 500.000 de angajaţi şi cu o cifră de afaceri totală de 50 miliarde de euro.

Table 1: The European leather industry in 2011

Tabelul 1: Industria europeană de pielărie în 2011

\begin{tabular}{|c|c|c|c|c|}
\hline Sector & $\begin{array}{c}\text { Companies } \\
\text { Companii }\end{array}$ & $\begin{array}{c}\text { Employees } \\
\text { Angajaţi }\end{array}$ & $\begin{array}{c}\text { Turnover } \\
\text { Cifră de afaceri } \\
(000000 €)\end{array}$ & $\begin{array}{c}\text { Extra-EU Export } \\
\text { Exporturi în afara UE } \\
(000000 €)\end{array}$ \\
\hline $\begin{array}{c}\text { Tanning } \\
\text { Pielărie (tăbăcării) }\end{array}$ & 1.783 & 34.504 & 7.750 & 2.307 \\
\hline $\begin{array}{c}\text { Footwear } \\
\text { Încălţăminte }\end{array}$ & 11.692 & 274.296 & 13.905 & 4.700 \\
\hline $\begin{array}{c}\text { Leather goods } \\
\text { Marochinărie }\end{array}$ & 10.710 & 83.464 & 9.541 & 4.066 \\
\hline TOTAL & 24.185 & 392.264 & 31.196 & 11.073 \\
\hline
\end{tabular}

Source: Eurostat, Entrepreneurial Association

Sursa: Eurostat, Asociaţii antreprenoriale

The roots of European tanning industry can be found in very ancient times. Pre-historic tanning activities have left little archeological remains apart of certain flaying tools, some products and certain references and ilustrative drawings. Quite a big well preserved tannery was discovered in the ruins of Pompei city (Italy), destroyed by the Vesuvio volcano more than two thousand years ago (August $24^{\text {th }} 79$ B.C.). Moreover, the importance of the industry has always been prominent for the European economy as, even at the beginning of the $20^{\text {th }}$ century, the tanning sector still was the one of the biggest industries of the whole area. Even if its incidence at global level has been declining in recent decades due to the growth of the sector in some emerging economies, the European tanning sector is still the global leader both in terms of:

a) turnover, covering $26.7 \%$ on world total (after China, accounting for $29.5 \%$ );

b) overall quality level reached by the industry through product and process innovation, as referred to technology (through a constant research on the
Industria europeană de pielărie îşi are rădăcinile în vremuri foarte vechi. Există puţine rămăşiţe arheologice lăsate în urma activităţilor de tăbăcire preistorice în afara unor unelte pentru jupuire, câteva produse şi anumite referinţe şi desene ilustrative. S-a descoperit o tăbăcărie destul de mare printre ruinele oraşului Pompei (Italia), distrus de vulcanul Vezuviu acum mai bine de două mii de ani (24 august 79 î.Hr.). Mai mult decât atât, importanţa industriei a fost dintotdeauna semnificativă pentru economia europeană, întrucât, chiar şi la începutul secolului XX, sectorul de pielărie reprezenta una din cele mai mari industrii de pe continent. Chiar dacă ponderea sa la nivel global a scăzut recent din cauza creşterii sectorului în anumite economii emergente, sectorul european de pielărie rămâne liderul global în ceea ce priveşte:

a) cifra de afaceri, reprezentând $26,7 \%$ din totalul la nivel mondial (după China, care totalizează 29,5\%);

b) nivelul de calitate generală atins de industrie prin inovare de produs şi proces; mai ales în ceea ce priveşte tehnologia (prin cercetare continuă privind 
processing cycle and product performance modernization), environmental performance (chemicals, water, solid waste and air emissions consequent to the tanning process are all treated and recycled), social commitment (relationships with workers and social dialogue with related trade unions have led to improved education and training and a constant reduction of injuries), design and style innovation (a very big importance is given to the research, the creation and the development of new fashion trends). According to last annual data available (2011), at present the sector is composed by nearly 1.800 companies and 34.500 workers. As outlined in the following graph (Figure 1), the trend in the last decade, following the production volume results, has been on the decrease for both elements: $25 \%$ for the number of companies, $-36 \%$ for employees.

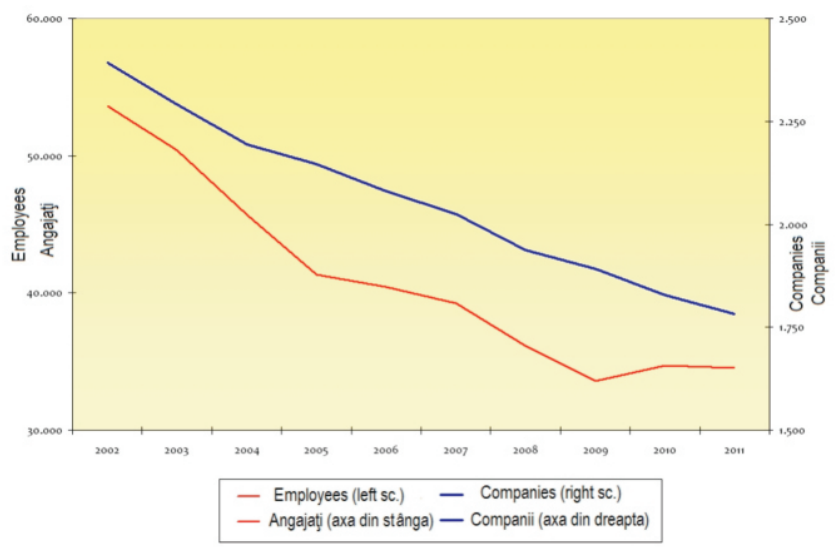

Figure 1. The European Tanning Industry -

Number of companies and employees

Source: Eurostat, Entrepreneurial Association

Figura 1. Industria europeană de pielărie (tăbăcării) Numărul de companii şi de angajaţi

Sursa: Eurostat, Asociaţii antreprenoriale

The tanning sector has traditionally been mainly composed by small and medium sized enterprises, but big companies have not been missing. At present, the average size of an EU tanning company is 18 person per enterprise and it is important to notice that in 2000 it was 24 with a continuous decline in the following years. This tendency seems to reveal that the resilience of the sector in the last decade can be illustrated by the topical sentence "Small is Beautiful". In other words, it ciclul de prelucrare şi performanţa produsului), angajamentul faţă de mediu (substanţele chimice, apa, deşeurile solide şi emisiile în aer rezultate în urma procesului de tăbăcire sunt tratate complet şi reciclate în proporţie de peste 90\%), angajamentul social (relaţiile extraordinare cu forţa de muncă şi dialogul social de pionierat cu sindicatele au îmbunătăţit nivelurile de educaţie şi formare a resurselor umane şi au dus la o scădere constantă a prejudiciilor), inovarea în design şi stil (se acordă o importanţă foarte mare studiului, creării şi dezvoltării de tendinţe în modă). Conform ultimelor date anuale disponibile (2011), în prezent, sectorul se compune din aproximativ 1.800 companii şi 34.500 muncitori. După cum ilustrează următorul grafic (Figura 1), în ultimul deceniu, în urma rezultatelor volumului de producţie, tendinţa a fost de scădere: $-25 \%$ pentru numărul de companii şi $-36 \%$ pentru numărul de angajaţi.

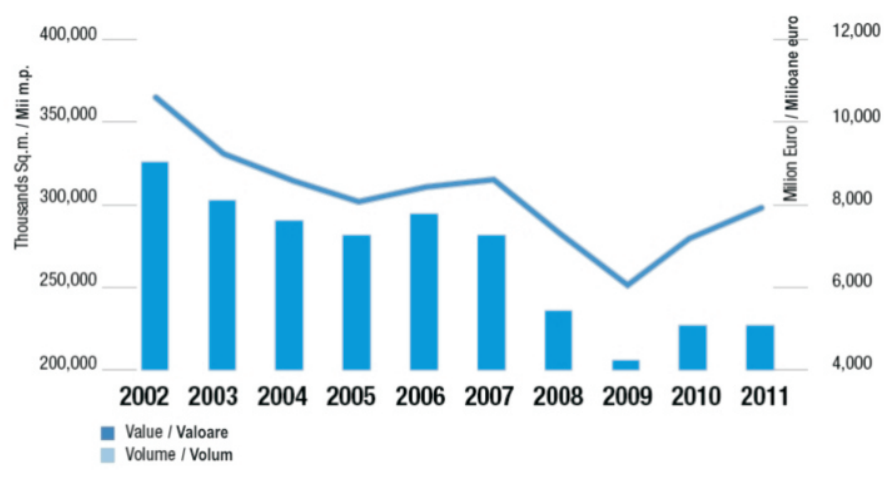

Figure 2. The European leather industry Production of leather (volume and value) Figura 2. Industria europeană de pielărie Producţia de piele (volum şi valoare)

Sectorul este, în mod tradiţional, compus în principal din întreprinderi mici şi mijlocii, dar există şi companii mari. În momentul de faţă, mărimea medie a unei tăbăcării din UE este de 18 persoane per întreprindere şi este important de menţionat că în anul 2000, media a fost de 24 de persoane per tăbăcărie, scăzând continuu în următorii ani. Această tendinţă pare să dezvăluie faptul că rezilienţa sectorului în ultimul deceniu poate fi ilustrată prin zicala 
appears that small and medium sized companies have been giving a better response to the big changes characterizing the world leather market in the first ten years of the new century. From this point of view, the European national industries present different characteristics, mostly depending on their productive specialization. The most important tanning sectors of Southern Europe (Italy, Spain, Portugal, France) are mainly composed by smaller undertakings. These countries are mostly specialized in the production of leather for fashion sectors, that often need a craftmanship approach that big companies are not able to provide. Conversely, the most important tanning sectors of Central and Northern Europe, focused on the upholstery destinations, present higher average dimensions of companies as economies of scale play a key role in these particular marketplaces.

In 2011, the total turnover of the EU tanning industry was 7.8 billion Euro, corresponding to a production of 224 millions sq.m. of finished leathers and about 44 thousands tons of sole leather (Figure 2).

Italy traditionally represents also the main tanning country in the European Union. Its share on total production is around $62 \%$ in terms of total EU tanning turnover and $60 \%$ in terms of volume. There has been just a little increase as compared to 2002, as in that year the country accounted for $60 \%$ in turnover and $57 \%$ in volume.

Spain ranks $2^{\text {nd }}$, covering 10/11\% (in volume and value) but registering a fall during the last decade (when its incidence was $12 / 13 \%$ ).

Austria, France, Germany and United Kingdom are actually around $3 \%$ to $6 \%$ on the EU total. There were no very big changes for them if compared to ten years ago although their product mix in terms of market destination may have changed. With the exceptions of Denmark, Luxembourg and Malta, all the others EU members still record the presence of tanners in their own territories.

The European leather production has always been very flexible, processing hides and skins from all the main animal origins and serving all the main client manufacturing utilizations.

The analysis of the production in terms of animal typology reveals that the main origin processed by the industry has always been hides of large bovines (71\% on total), followed by sheepskins (14\%), then goat skins contemporană "Mai mic înseamnă mai frumos". Cu alte cuvinte, companiile mici şi mijlocii par să fi avut o reacţie mai bună la marile schimbări ce au caracterizat piaţa mondială de pielărie în primii zece ani ai noului mileniu. Din acest punct de vedere, industriile naţionale europene prezintă caracteristici diferite, depinzând, în mare măsură, de specializarea acestora. Cele mai importante sectoare de pielărie din Europa de Sud se compun în principal din întreprinderi mai mici. Aceste ţări sunt specializate în principal în producţia de piele pentru sectoarele de modă, care deseori necesită o abordare artizanală pe care companiile mai mari cu greu o pot oferi. În schimb, cele mai importante sectoare de pielărie din Europa Centrală şi de Nord s-au concentrat pe tapiţerie şi au companii cu mărimi medii mai mari, întrucât economiile lor joacă un rol important pe aceste pieţe.

În 2011, cifra de afaceri totală a industriei europene de pielărie a fost de 7,8 miliarde de euro, corespunzând unei producţii de 224 milioane de metri pătraţi de piei finite şi aproximativ 44 de mii de tone de piei talpă (Figura 2).

Italia reprezintă, în mod tradiţional, principala ţară din Uniunea Europeană la capitolul procesare piei tăbăcării. Ponderea sa din producţia totală de piei UE este de aproximativ $62 \%$ pentru cifra de afaceri şi $60 \%$ pentru volum în 2011. A avut loc o mică creştere în comparaţie cu 2002, în acel an înregistrându-se $60 \%$ pentru cifra de afaceri şi $57 \%$ pentru volum.

Spania este pe locul 2, având 10/11\% (în volum şi valoare) şi prezentând o scădere în ultimul deceniu (când ponderea sa era de 12/13\%).

Austria, Franţa, Germania şi Regatul Unit deţin aproximativ $3 \%$ până la $6 \%$ din total. Nu au existat schimbări semnificative pentru acestea faţă de acum zece ani, deşi gama de produse (ca destinaţii de utilizare finală) este posibil să se fi modificat. $\mathrm{Cu}$ excepţia Danemarcei, Luxemburgului şi a Maltei, în toate celelalte state membre ale UE se înregistrează prezenţa tăbăcăriilor pe propriile teritorii.

Producţia europeană de piele a fost întotdeauna foarte flexibilă, prelucrând piei de orice origine animală şi deservind toate utilizările finale principale.

Analiza producţiei în ceea ce priveşte tipologia animală dezvăluie că industria a prelucrat întotdeauna cu precădere piei de bovine mari ( $71 \%$ din total), urmate de piei ovine (14\%), piei caprine (8\%) şi piei de 
(8\%) and calf skins (6\%). The remaining animal raw materials processed (principally hides and skins from reptiles, pigs, deer...) cover a very small part of the industry (less than 1\%) and can be considered as niches. This segmentation, that is strictly linked to the meat industry, has never shown very big modifications.

The principal destination use of leather, not only in Europe, has traditionally been the production of leather for uppers for the footwear sector. That is still the first manufacturing client of the EU leather industry ( $41 \%$ on total). In spite of the big fall suffered by the market destination in the furniture sector during the recent years, the second most important utilization of EU leather is for upholstery; divided into furniture $(17 \%)$ and car interiors (13\%). Leather goods covers $19 \%$, while garments presently absorbs $8 \%$ ( $2 \%$ for the remaining niche segments).

As mentioned, the European tanning industry is a world leader in terms of quality, and quality means value. EU leather covers the top ranges of production in all the main specialisations and uses. In the fashion area, top ranges mainly mean the best design, style and creativity in the world; in the upholstered sectors (beside the mentioned innovation factors) they comprise the best reliability, standardisation and performance that can be found at a global level in top range passenger cars. These are key elements difficult to find on mass markets. Success for a European tanner is increasingly linked to his capacity to be efficient and innovative.

\section{Characterisation of the Sample}

The active cooperation of 7 national associations (Italy, Spain, France, Germany, UK, Sweden, Romania), has allowed collecting first hand data from a highly significant sample that represents $90.9 \%$ of EU companies, $76.6 \%$ of the workforce, $87.8 \%$ of the turnover.

Social and environmental indicators have been collected and elaborated by the associations at national level and aggregated at European level. The document provides a detailed description of the indicators and their relevance both from a social and an environmental point of view for the years 2010 and 2011.

All the social and environmental indicators and data presented in the paper have been obtained through the active cooperation of seven national viţel (6\%). Restul tipurilor de piei animale prelucrate (în principal reptile, porcine, căprioare...) reprezintă o foarte mică parte (mai puţin de 1\%) şi pot fi considerate producţii de nişă. Această segmentare, strict legată de industria de carne, nu a avut niciodată variaţii semnificative.

Principala destinaţie de utilizare a pielii, nu numai în Europa, a fost, în mod tradiţional, producţia de feţe de încălţăminte pentru sectorul de încălţăminte. Acesta a rămas principalul client pentru pielea europeană ( $41 \%$ din total). În ciuda celei mai mari scăderi din punct de vedere al pieţei de destinaţie din ultimii ani, industria de tapiţerie mobilă/auto rămâne a doua utilizare ca importanţă; aceasta se împarte în mobilă (17\%) şi interioare auto (13\%). Marochinăria preia $19 \%$ din producţia europeană de piele, în timp ce îmbrăcămintea deţine în prezent doar $8 \%$ (lăsând $2 \%$ pentru segmentele de nişă rămase).

După cum s-a menţionat, industria europeană de pielărie este un lider mondial în ceea ce priveşte calitatea, iar calitatea înseamnă valoare. Pielea din UE acoperă intervalele de vârf de producţie din toate specializările şi utilizările principale. În aria modei, intervalele de vârf înseamnă cu precădere cel mai bun design, stil şi creativitate din lume; în sectoarele de tapiţerie (pe lângă factorii de inovare menţionaţi), acestea cuprind fiabilitate, standardizare şi performanţă maxime care pot fi găsite la nivel global în gama autoturismelor de vârf. Acestea sunt elemente cheie dificil de găsit pe pieţele cu producţie de masă. Pentru tăbăcarii europeni, succesul este corelat din ce în ce mai mult cu capacitatea lor de a fi eficienţi şi inovatori.

\section{Caracterizarea eşantionului}

Cooperarea activă a 7 asociaţii naţionale (Italia, Spania, Franţa, Germania, Regatul Unit, Suedia, România) a permis elaborarea de date care decurg dintr-un eşantion foarte semnificativ, reprezentând $90,9 \%$ din firmele europene, $76,6 \%$ din forţa de muncă şi $87,8 \%$ din cifra de afaceri.

Asociaţiile naţionale au obţinut şi elaborat indicatorii sociali şi de mediu, care au fost apoi agregaţi la nivel european. Articolul oferă o descriere detaliată a indicatorilor ce privesc atât performanţa socială, cât şi cea de mediu pentru anii 2010 şi 2011.

Toţi indicatorii sociali şi de mediu, precum şi datele prezentate în acest articol au fost obţinute prin cooperarea activă a şapte asociaţii naţionale, membre 
leather trade association members of Cotance, representing the tanning industries of Italy, Spain, France, Germany, United Kingdom, Sweden and Romania.

The work of the associations mainly consisted of elaborating social and environmental data and indicators at national level, carrying out surveys and interviews with their affiliated companies, on the basis of a specific questionnaire structured according to the economic, social and environmental indicators agreed by the sector's EU Social Partners in their 2008 Framework Agreement (Standard for Social \& Environmental Reporting in the European Leather Industry).

In this exercise the sample has been constructed with the main aim of not only being representative in terms of number of companies and workers, but also reflecting the main characteristics in terms of products, organisation of production and markets. Criteria used to define the sample structure also included aspects such as geographical distribution (i.e. organisation in tanning clusters), production per animal type and per end use market segment. Having regard to the countries and sectors that contributed their data to the present report, it can be said that the sample is representative and that it represents very well the variety of the European tanning industry, where Italy plays a major role, comprising $71 \%$ of the turnover of the sample, $80 \%$ of the companies and $68 \%$ of the workforce (Figures 3-5).

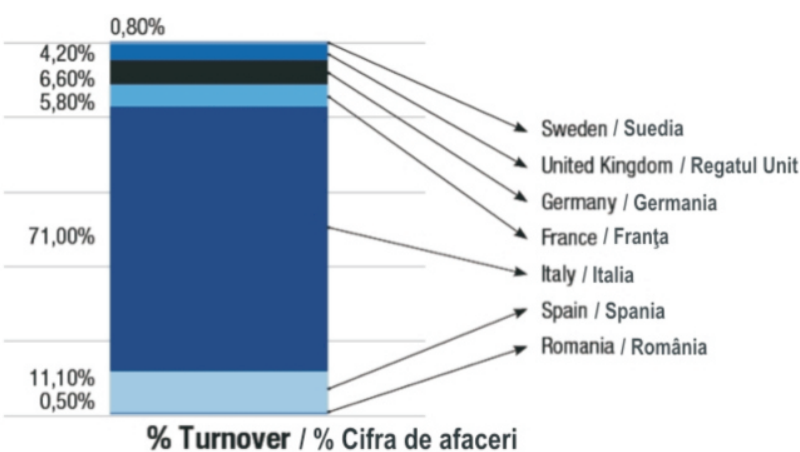

Figure 3. Sample structure: Percentage on value of production Figura 3. Structura eşantionului: procent din valoarea producţiei ale COTANCE, reprezentând industriile de pielărie din Italia, Spania, Franţa, Germania, Regatul Unit, Suedia şi România.

Activitatea asociaţiilor a constat în principal în elaborarea de date şi indicatori sociali şi de mediu la nivel naţional, efectuarea de studii şi interviuri cu companiile afiliate acestora, pe baza unui chestionar specific structurat în funcţie de indicatori economici, sociali şi de mediu conveniţi de către partenerii sociali din UE din acest sector în Acordul cadru din 2008 (Standard pentru raportarea socială şi de mediu în industria europeană de pielărie).

În acest exerciţiu, eşantionul a fost constituit cu scopul principal de a nu fi doar reprezentativ cu privire la numărul de întreprinderi şi lucrători, dar şi pentru a reflecta caracteristicile principale în ceea ce priveşte produsele, organizarea producţiei şi pieţele. Criteriile utilizate pentru a defini structura eşantionului au inclus, de asemenea, aspecte precum distribuţia geografică (organizarea în grupuri/clustere de tăbăcării), producţie per tip de animal şi per segmentul de piaţă al utilizării finale. Referitor la ţările şi sectoarele care au contribuit cu datele lor la raportul de faţă, se poate spune că eşantionul este reprezentativ şi că reprezintă foarte bine varietatea industriei europene de pielărie, în care Italia joacă un rol major, reprezentând $71 \%$ din cifra de afaceri a eşantionului, $80 \%$ din numărul de companii şi $68 \%$ din forţa de muncă (Figurile 3-5).

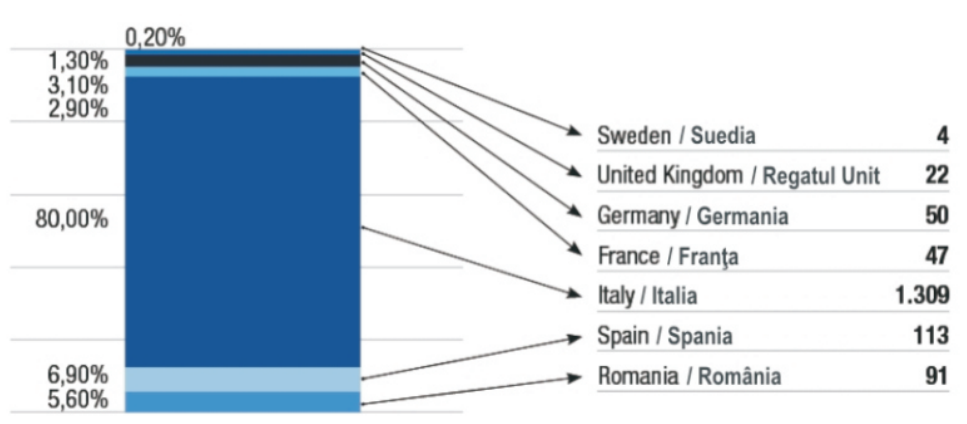

Figure 4. Sample structure: Percentage on number of companies

Figura 4. Structura eşantionului: procent din numărul de companii 


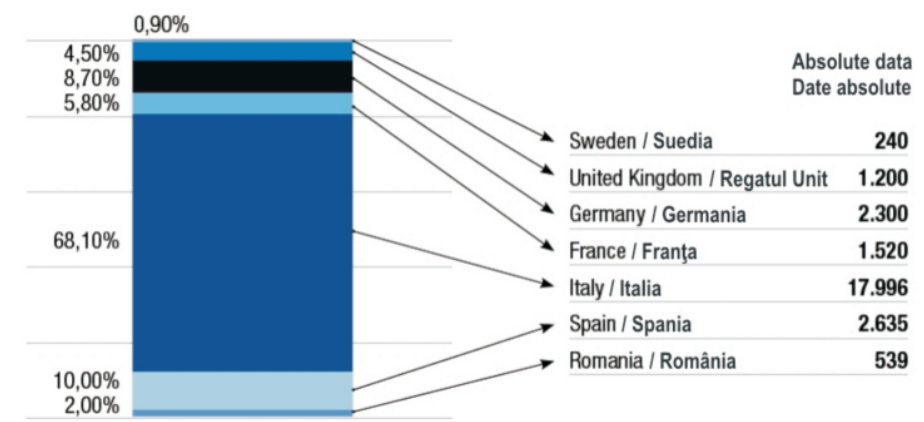

$\%$ Number of employees / \% Număr angajaţi

Figure 5. Sample structure:

Percentage on number of employees

Figura 5. Structura eşantionului: procent din numărul de angajaţi

As shown in Figure 6, the sample mirrors the sector in one more of its particular characteristics: small company size. The European tanning sector is typically composed of small and medium sized enterprises; this is in some cases a competitive advantage for responding to the changes seen in the markets over time. The average size per country furthermore provides an indication of the market destination of the leathers produced: Italy, Spain and France are on average more specialised in fashion, where a smaller size ensures corporate flexibility. On the other hand, bigger average sizes are seen in central and northern European countries of the sample (United Kingdom, Germany, Sweden), where a more industrial approach has prevailed with the automotive sector as a major client. Production per animal type in the sample (Figure 7) reflects perfectly the characteristic distribution of European production, where adult bovines, calves, sheep and goats, compose the largest share of raw materials. A residual share of production is based on other animal types (such as pig skins, deerskins and noble furs), which constitute significant shares of production in certain countries. Again, mirroring the European reality, the end use market segment of leathers captured by the sample is predominantly footwear, followed by upholstery (furniture, car interiors \& others) and leathergoods (Figure 8).

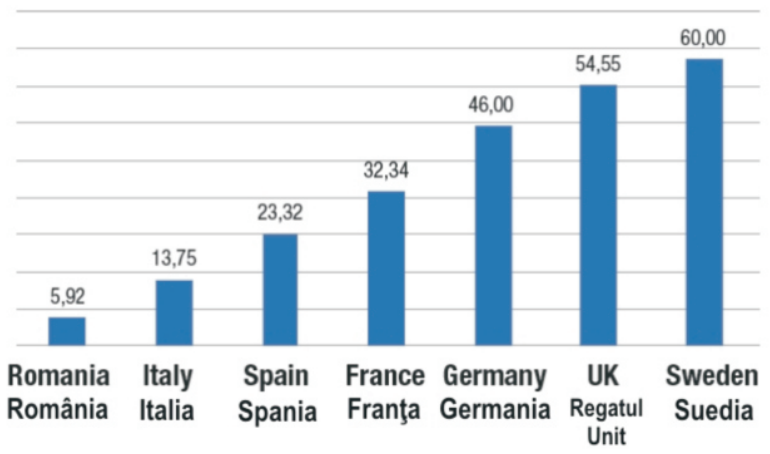

Figure 6. Sample characterisation:

Average company size

Figura 6. Caracterizarea eşantionului: mărimea medie a companiilor

Aşa cum se arată în Figura 6, eşantionul reflectă una din caracteristicile specifice sectorului: companii de dimensiuni mici. Sectorul european de pielărie este de obicei compus din întreprinderi mici şi mijlocii; acesta este, în unele cazuri, un avantaj competitiv pentru a răspunde la schimbările observate pe pieţe de-a lungul timpului. Dimensiunea medie pe ţară oferă în plus o indicaţie a pieţei de destinaţie a pieilor produse: Italia, Spania şi Franţa sunt, în medie, mai specializate în modă, iar dimensiunea mai mică asigură flexibilitatea companiei. Pe de altă parte, se observă dimensiuni medii mai mari în ţări din Europa centrală şi de nord ale eşantionului (Marea Britanie, Germania, Suedia), unde a dominat o abordare industrială, iar în sectorul automobilelor este clientul majoritar. Producţia per tip de animal în cadrul eşantionului (Figura 7) reflectă perfect distribuţia caracteristică a producţiei europene, în care bovinele, viţeii, ovinele şi caprinele adulte reprezintă cea mai mare parte a materiilor prime. Restul producţiei se bazează pe alte tipuri de animale (cum ar fi piei de porc, căprioare şi blănuri nobile), care constituie ponderi semnificative ale producţiei în anumite ţări. Din nou, reflectând realitatea europeană, segmentul de piaţă al utilizării finale a pieilor luate în eşantion este în principal cel al încălţămintei, urmat de tapiţerie (mobilier, interioare auto şi altele) şi marochinărie (Figura 8). 


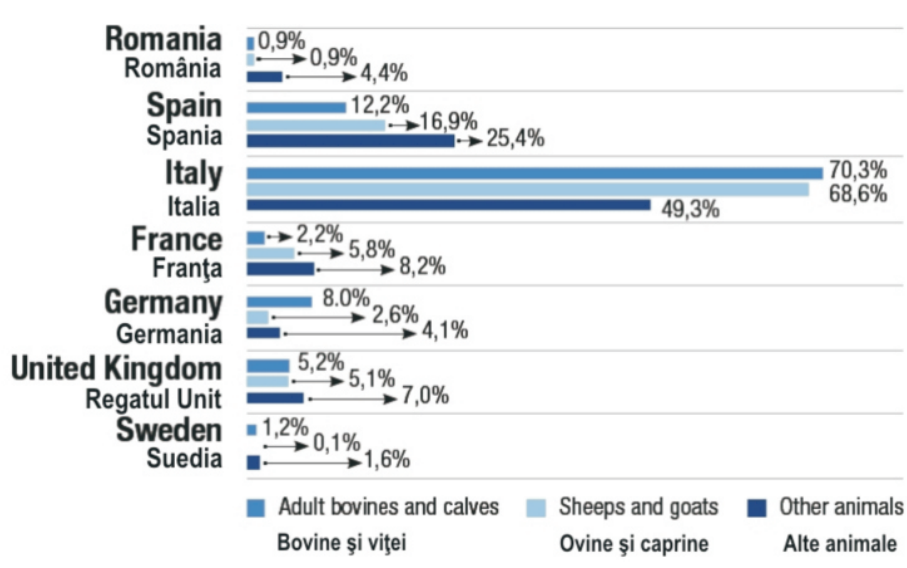

Figure 7. Sample characterisation: Production per animal tipology

Figura 7. Caracterizarea eşantionului: producţie per tipologie animal

\section{SOCIAL INDICATORS}

Human capital is essential for the European tanning industry. The combination of experience and youth, i.e. skilled workers and young applicants, represents the key asset on which the competitiveness of the sector is based.

Tanneries in Europe are increasingly committed to the ethical and social aspects of their business. They understand this development as a means of enhancing and strengthening the relationship with their stakeholders; workers, customers, suppliers, bankers, public authorities, civil society and territories.

The present chapter of the report provides a picture of the social dimension of the European tanning sector, on the basis of a selection of indicators: Job categories, Contractual types, Age brackets, Education, Seniority, Territorial origin, Gender equality, Membership in Trade unions, Accidents and Employee benefits, such as arrangements for sickness leave.

The situation that emerges from the analysis of the information collected shows a sector that is firmly rooted in the territory and deeply committed - in collaboration with partners and public authorities to combining industrial growth with the continuous improvement of working conditions, the generation of wealth in the territory and the enhancement of the quality of life in local communities. The social situation within the tanneries is characterised, above all, by the

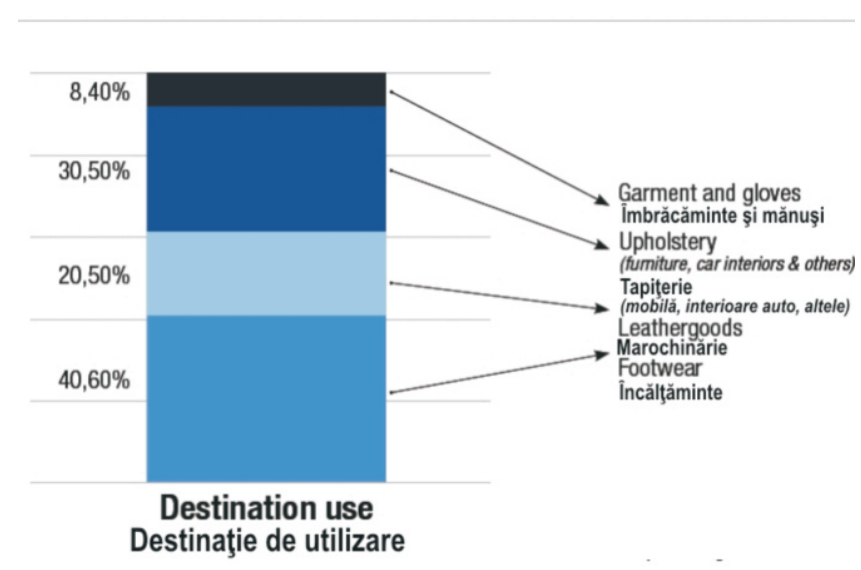

Figure 8. Sample characterisation: Production per destination use

Figura 8. Caracterizarea eşantionului: producţie per destinaţie de utilizare

\section{INDICATORISOCIALI}

Capitalul uman este esenţial pentru industria europeană de pielărie. Combinaţia de experienţă şi tinereţe, adică muncitori calificaţi şi solicitanţi tineri, reprezintă atuul-cheie pe care se bazează competitivitatea sectorului.

Tăbăcarii din Europa sunt din ce în ce mai angajaţi în aspectele etice şi sociale ale activităţii lor. Ei înţeleg această dezvoltare ca pe un mijloc de a îmbunătăţi şi consolida relaţiile lor cu părţile interesate: lucrătorii, clienţii, furnizorii, bancherii, autorităţile publice, societatea civilă şi teritorială.

Prezentul capitol al raportului oferă o imagine a dimensiunii sociale a sectorului european de pielărie, pe baza unei selecţii de indicatori: categorii de locuri de muncă, tipuri de contracte, grupe de vârstă, educaţie, vechime, origine teritorială, egalitatea de gen, calitatea de membru în sindicate, accidente şi beneficii pentru angajaţi, cum ar fi aranjamentele pentru concediul medical.

Situaţia care reiese din analiza informaţiilor colectate arată un sector care este ferm înrădăcinat în teritoriu şi profund angajat - în colaborarea cu partenerii şi autorităţile publice pentru a combina creşterea industrială cu îmbunătăţirea continuă a condiţiilor de muncă, generarea de bogăţie în teritoriu şi îmbunătăţirea calităţii vieţii în comunităţile locale. Situaţia socială în cadrul tăbăcăriilor se caracterizează, mai presus de toate, printr-o cooperare fructuoasă 
fruitful cooperation between the social partners. Apart from the institutional role that the representative bodies of the social dialogue play during collective negotiations, both sides of the European tanning sector also provide the example of how a close cooperation contributes to reinforcing Europe's leather industry against global competition, and to promoting the social values linked to European leather on global markets.

The structure of the workforce in tanneries sees the predominance of professional profiles with technical and production oriented skills (79\% of the workforce).

As illustrated in Figure 9, low specialisation production workers prevail in the shop floor (over 66\% in 2010 and 2011), while highly skilled personnel tend to be higher in other departments or services. Indeed, Research and Development related jobs are increasing their importance both in the area of process technologies and fashion, design and style.

The low incidence of managerial jobs is mainly due to the predominance of small and medium sized enterprises (often family businesses), where practical decision-making responsibilities are usually delegated to personnel with proven experience but in a middle management position.

As shown in Figure 10, more than $87 \%$ of the workforce of European tanneries are employed with a permanent e contract. Different forms of fixed-term employment contracts make up the balance.

In 2010 and 2011 the distribution of job categories saw a prevalence of blue collars with low and high specialisations.

In both years surveyed, the vast majority of contractual types is represented by permanent employment contracts.

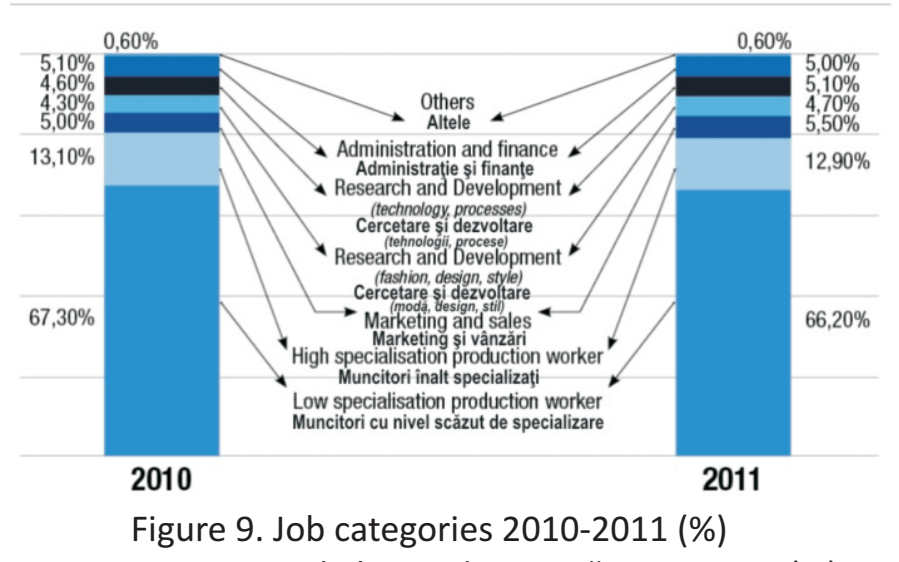

Figura 9. Categorii de locuri de muncă 2010-2011 (\%) între partenerii sociali. În afară de rolul instituţional pe care îl joacă organele reprezentative ale dialogului social în cadrul negocierilor colective, ambele părţi ale sectorului european de pielărie oferă, de asemenea, exemplul modului în care o cooperare strânsă contribuie la consolidarea industriei europene faţă de concurenţa la nivel mondial, precum şi la promovarea valorilor sociale legate de pielea europeană pe pieţele mondiale.

În structura forței de muncă din tăbăcării predomină profilurile profesionale cu competenţe orientate spre tehnică şi producţie (79\% din forţa de muncă).

Aşa cum este ilustrat în Figura 9, muncitorii cu nivel scăzut de specializare predomină în secţia de producţie (peste 66\% în 2010 şi 2011), în timp ce personalul cu calificare înaltă tinde să fie mai mare în alte departamente sau servicii. Într-adevăr, importanţa locurilor de muncă în cercetare şi dezvoltare este în creştere, atât în domeniul tehnologiilor de proces, cât şi în design, modă şi stil.

Incidenţa scăzută a posturilor de conducere se datorează în principal predominanţei întreprinderilor mici şi mijlocii (de multe ori întreprinderi familiale), unde responsabilităţile practice de luare a deciziilor sunt de obicei delegate personalului cu experienţă dovedită, dar într-o poziţie de conducere intermediară.

Aşa cum arată Figura 10, mai mult de $87 \%$ din personalul din tăbăcăriile europene este angajat cu contract de muncă permanent. Echilibrul este păstrat de diferite forme de contracte de muncă pe durată determinată.

În 2010 şi 2011, în distribuţia categoriilor de locuri de muncă a predominat cea a muncitorilor cu nivel scăzut sau ridicat de specializare.

În ambii ani studiaţi, marea majoritate a tipurilor de contracte o reprezintă contractele de muncă permanente.

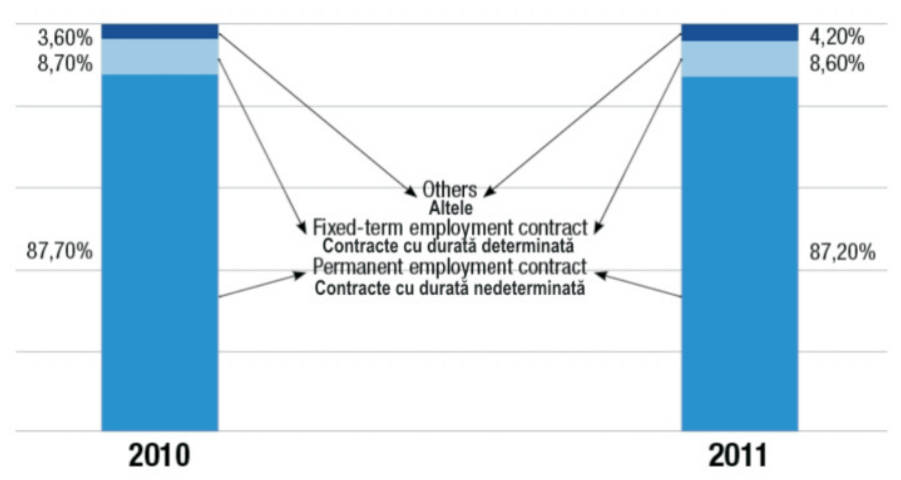

Figure 10. Contractual types 2010-2011 (\%)

Figura 10. Tipuri de contracte 2010-2011 (\%) 
Figure 11 shows a quite consistent distribution. Workers under 35 years of age represent almost $30 \%$ of the total in 2011. The age bracket of those employees aged between 35 and 55 displays the largest incidence in both years under consideration. Studies carried out at EU level show that one of the most relevant issues for Europe's tanneries is the low appeal of the sector among young people. Many initiatives involving schools and teachers are in place for reversing this trend. National associations and trade unions are generally their promoters, but results show that a more comprehensive effort at European level is necessary to renew the sector's workforce on a sustainable basis.

Figure 12 illustrates the results of the survey in terms of Seniority. More than $50 \%$ of the workforce has been employed in the tanning sector for less than 10 years, while a significant share of the total remain in tannery jobs for a large portion of their working life.

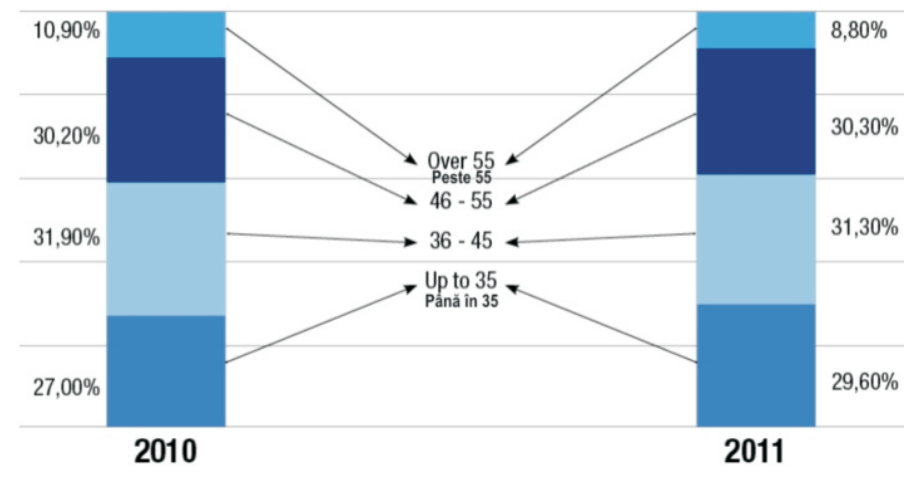

Figure 11. Age brackets 2010-2011 (\%)

Figura 11. Categorii de vârstă 2010-2011 (\%)

The job distribution depicted in Figure 9 mirrors the analysis of the educational level, shown in Figure 13. ISCED levels 1 and 2, corresponding respectively to Primary education or first stage of basic education and to Lower secondary or second stage of basic education, represent the same share of the total (almost 70\%) as the low specialisation production workers employed in tanneries (66.2\% in 2011).
Figura 11 arată o distribuţie destul de uniformă. Muncitorii sub 35 de ani reprezintă aproape 30\% din total în 2011. Categoria angajaţilor cu vârste cuprinse între 35 şi 55 de ani prezintă cea mai mare incidenţă în ambii ani luaţi în considerare. Studiile efectuate la nivelul UE arată că una dintre problemele cele mai relevante pentru tăbăcarii din Europa este interesul scăzut al tinerilor faţă de sector. Multe iniţiative care implică şcolile şi profesorii sunt în vigoare pentru inversarea acestei tendinţe. Promotorii sunt, în general, asociaţiile naţionale şi sindicatele, dar rezultatele arată că este necesar un efort mai mare, concentrat la nivel european pentru a reînnoi forţa de muncă în acest sector pe baze durabile.

Figura 12 ilustrează rezultatele sondajului în ceea ce priveşte vechimea. Mai mult de $50 \%$ din forţa de muncă a fost angajată în sectorul de pielărie de mai puţin de 10 ani, în timp ce o parte semnificativă din total lucrează în tăbăcărie în cea mare parte a vieţii.

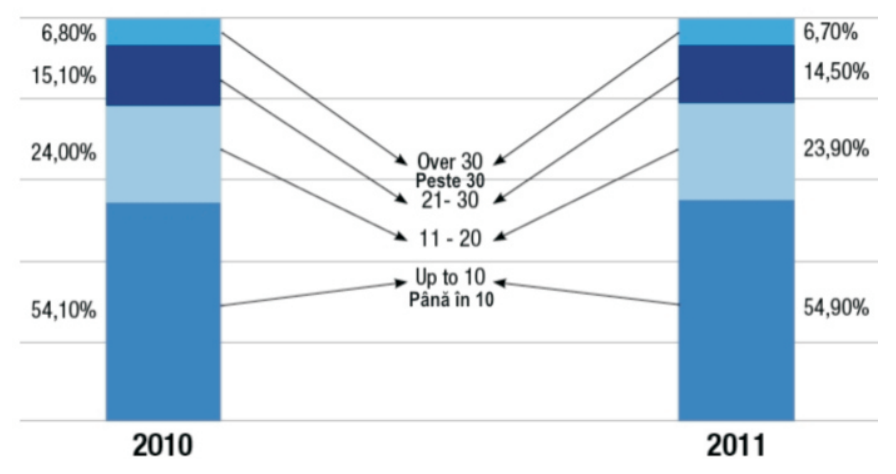

Figure 12 . Seniority categories $2010-2011(\%)$

Figura 12. Categorii de vechime 2010-2011 (\%)

Distribuţia locurilor de muncă reprezentate în Figura 9 reflectă analiza nivelului educaţional, indicat în Figura 13. Nivelurile ISCED 1 şi 2 , care corespund învăţământului primar sau primei trepte a educaţiei de bază şi celui gimnazial sau celei de a doua treaptă a educaţiei de bază, reprezintă aceeaşi pondere din total (aproape 70\%) cu cea a muncitorilor cu nivel scăzut de specializare angajaţi în tăbăcării (66,2\% în 2011). 


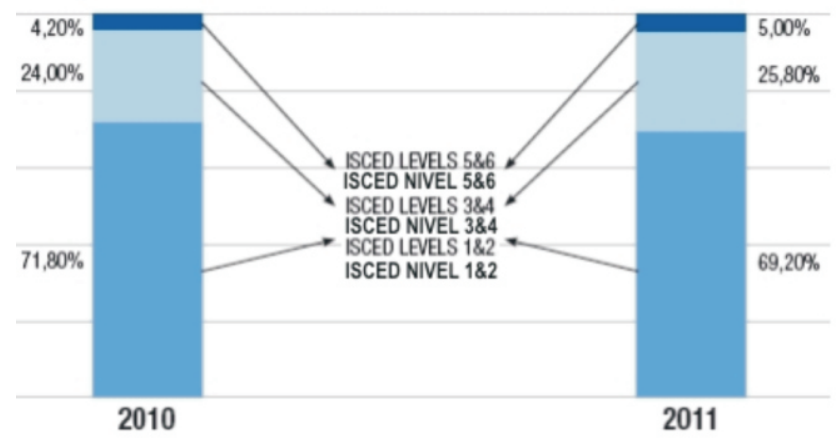

Figure 13. Education 2010-2011 (\%)

Figura 13. Educaţie 2010-2011 (\%)

The tanning sector is traditionally closely and firmly rooted in its territory. Figure 14 shows that a very large share of the workers in European tanneries comes from the same country of the tannery they work for. In some cases, hiring is performed predominantly in the very area (city or province) where the tanneries are based. Immigration and integration of foreign workers is nevertheless a noticeable feature. Another significant share of workers (9.2\% in 2011) comes from foreign non-European countries. This exemplifies the positive interaction of Europe's tanneries with their local communities where leather often represents the main employment opportunity that also contributes to the integration of immigrants at local and regional level.

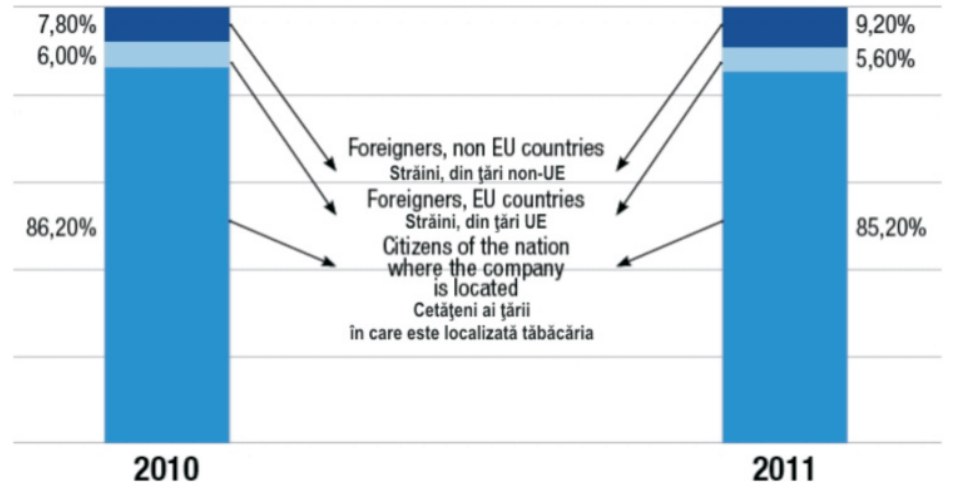

Figure 14. Territorial origin 2010-2011 (\%)

Figura 14. Origine teritorială 2010-2011 (\%)

Sectorul de pielărie este în mod tradiţional foarte bine înrădăcinat în teritoriul său. Figura 14 arată că o pondere foarte mare a muncitorilor din tăbăcăriile europene provin din aceeaşi ţară în care se află tăbăcăria în care lucrează. În unele cazuri, angajarea se face în principal chiar în zona în care se situează tăbăcăriile (oraş sau provincie). Imigraţia şi integrarea muncitorilor străini este totuşi o caracteristică vizibilă. O altă pondere importantă a muncitorilor $(9,2 \%$ în 2011) vine din ţări străine non-europene. Aceasta exemplifică interacţiunea pozitivă a tăbăcăriilor din Europa cu comunităţile lor locale în care domeniul pielăriei reprezintă adesea principala posibilitate de ocupare a forţei de muncă, care contribuie şi la integrarea imigranţilor la nivel local şi regional.

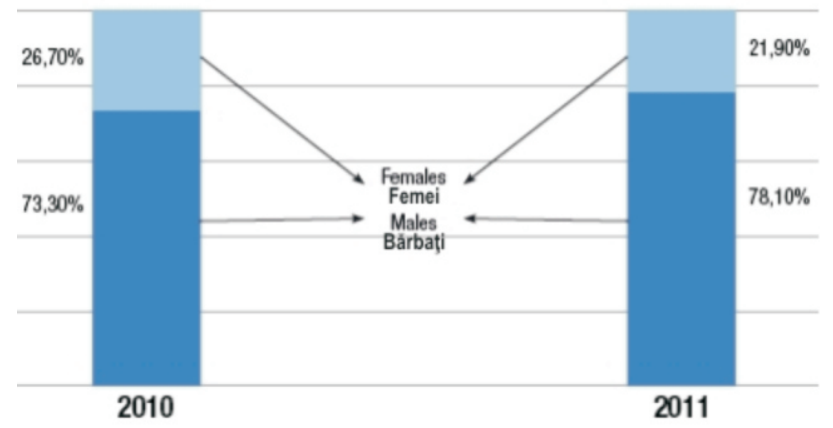

Figure 15. Gender distribution 2010-2011 (\%)

Figura 15. Distribuţia în funcţie de gen 2010-2011 (\%)

As shown in Figure 15, the gender distribution in the sector is somehow mirroring the picture of job distribution, with similar percentages of low specialisation production workers and males. This predominance of male employment at the shop floor is more frequent in tanneries processing whole bovine
Aşa cum arată Figura 15, distribuţia în funcţie de gen în sector reflectă cumva distribuţia locurilor de muncă, muncitorii cu nivel scăzut de specializare şi bărbaţii având procente similare. Predominanţa bărbaţilor în secţia de producţie se întâlneşte mai mult în tăbăcăriile care prelucrează piei bovine întregi, a căror 
hides where the loads handled usually call for a certain physical strength. Indeed, it is not unusual to find women working in production in tanneries processing small skins. Female jobs are, however, quite equally distributed in production and in other office based processes. Female jobs, even if inferior in number, are equally distributed in production and in administration.

\section{Accidents}

Workplace risk prevention is high on the sector's agenda where the handling of loads, the use of heavy machinery and specialty chemicals could be the source of severe injuries.

In Europe tanning is not an accident-intensive industrial activity. At least this is what the survey results suggest for the period under review. Accidents have been analysed taking into consideration three indicators: (1) Relative frequency: total number of accidents*1000/number of workers; (2) Seriousness ratio: days lost/number of workers; (3) Average duration: number of days absent from work/number of accidents.

Data referred to 2011 and only to the Italian situation (in any case highly representative). Figures are as follows: (i) Relative frequency: 3.35 ; (ii) Seriousness ratio: 0.93; (iii) Average duration: 27.63.

These figures are low in comparison with other industrial sectors. Italy moreover records a long period without fatal accidents in the tanning sector.

\section{A Productive Social Dialogue}

The Social Partners of the European Leather industry, COTANCE and IndustriAll (former ETUF:TCL), have developed a fruitful Social Dialogue since the 1990s.

Within the EU Sector Social Dialogue Committee Leather/Tanning, they adopted a joint declaration in 1999 on training requirements in the context of the modernisation of work organisation, improving the image of the sector and establishing a unit to monitor industrial change.

In 2000, they drew up a Code of good Conduct concerning fundamental rights at work; this was their first Framework Agreement. They drafted joint contributions for the Lisbon (2001), Barcelona (2002) and Brussels (2004) Summits on the challenges and opportunities of the sector. They organised a workshop on training themes in Turin, Italy in 2002 and a seminar prelucrare necesită, de obicei, o anumită rezistenţă fizică. Femeile angajate în producţie se ocupă, de regulă, de prelucrarea pieilor mici. Locurile de muncă pentru femei sunt, totuşi, distribuite în mod egal în producţie şi în alte activităţi ce ţin de munca de birou. Chiar dacă sunt mai mici ca număr, locurile de muncă pentru femei sunt distribuite egal în producţie şi administraţie.

\section{Accidente}

Prevenirea riscurilor la locul de muncă este o prioritate a sectorului în care manipularea încărcăturilor, operarea utilajelor grele şi utilizarea substanţelor chimice speciale pot fi o sursă de leziuni grave.

În Europa, tăbăcirea pieilor nu este o activitate industrială care să predispună la accidente. Cel puţin aceasta sugerează rezultatele studiului pentru perioada analizată. Accidentele au fost analizate luând în considerare trei indicatori: (1) Frecvenţa relativă: număr total de accidente*1000/număr de muncitori; (2) Indice de gravitate: zile pierdute/ număr de muncitori; (3) Durata medie: număr de zile de absenţă de la muncă /număr de accidente.

Datele se referă la anul 2011 şi doar la situaţia din Italia (care este foarte reprezentativă). Cifrele sunt următoarele: (i) Frecvenţa relativă: 3,35; (ii) Indice de gravitate: 0,93; (iii) Durata medie: 27,63.

Aceste cifre sunt mici în comparaţie cu alte sectoare industriale. Mai mult, în Italia se înregistrează o perioadă lungă fără accidente fatale în sectorul de prelucrare piei.

\section{Un dialog social productiv}

Partenerii sociali din industria europeană de pielărie, COTANCE şi IndustriAll (fostul ETUF: TCL), au dezvoltat un dialog social fructuos încă din anii 1990.

În cadrul Comitetului de Dialog Social pentru Sectorul de Pielărie/Tăbăcării din UE, în anul 1999 au adoptat o declaraţie comună privind cerinţele de formare profesională în contextul modernizării organizării muncii, îmbunătăţirii imaginii sectorului şi instituirii unei unităţi pentru a monitoriza schimbările industriale.

În anul 2000, au elaborat un Cod de Conduită în ceea ce priveşte drepturile fundamentale la locul de muncă; acesta a fost primul lor acord-cadru. Au elaborat contribuţii comune pentru Summit-urile de la Lisabona (2001), Barcelona (2002) şi Bruxelles (2004) privind provocările şi oportunităţile sectorului. Au organizat un atelier de lucru pe teme de formare în 
on the modernisation of work organisation (Spain, 2002).

In the context of enlargement, they organised three Economic and Social Forums with EU candidate countries (Hungary (2001), Romania (2002), Poland (2004)). The Social Partners have undertaken in 2003/2004 a joint project with SAI (Social Accountability International) on training on Core Labour Standards in support of the implementation of their Code of Conduct.

In 2005, the social partners of the tanning and those of the textile sectors launched a joint Capacity Building project for the Social Partners from the new member States and EU accession candidate countries.

As a follow-up of their 2000 Code of Conduct, they developed a new Framework Agreement in 2008 focussing on an innovative Standard for Social \& Environmental Reporting in Europe's leather industry empowering even the sector's SMEs to adopt CSR communication practices.

A number of other joint projects regarding highly relevant sector issues such as developing in 2011 an On-line Risk Assessment Tool for the sector's SMEs (http://client.oiraproject.eu) or addressing Transparency and Traceability of the supply chain (2012) complete the range of activities of the Social Partners of the European Leather Industry.

\section{Training Activities}

Human resources being so crucial for the sector's competitiveness, all European tanneries understand the importance of training their workforce. For competing in the international market on quality, product consistency and performance, fashion and service to customers, skilled personnel are essential, notably in high-cost economies such as Europe. The combination of experience and youth, i.e. skilled workers and young applicants, represents the key asset on which the competitiveness of the sector is based. This can be enhanced at sector level by developing continuing vocational training and life-long learning.

Despite a long tradition and the international reputation of Europe's tanning schools and dedicated university departments and chairs, leather specific education and training in Europe is in distress. Critical mass for filling classrooms, geographical dispersion of tanneries and language barriers are some of the obstacles facing an effective
Torino, Italia, în 2002 şi un seminar privind modernizarea organizării muncii (Spania, 2002).

În contextul extinderii, au organizat trei forumuri economice şi sociale cu ţările candidate la UE (Ungaria (2001), România (2002), Polonia (2004)). Partenerii sociali s-au angajat în 2003/2004 într-un proiect comun cu SAI (Social Accountability International) pentru formarea privind standardele fundamentale în domeniul muncii în sprijinul punerii în aplicare a Codului de Conduită.

În anul 2005, partenerii sociali ai sectoarelor de pielărie şi textile au lansat un proiect comun de dezvoltare a capacităţilor pentru partenerii sociali din noile state membre şi ţările candidate pentru aderare la UE.

Ca activitate ulterioară a Codului lor de Conduită din 2000, au dezvoltat un nou acord-cadru în 2008, concentrându-se asupra unui Standard inovator pentru Raportarea Socială şi de Mediu în industria europeană de pielărie dând şi IMM-urilor din sector posibilitatea de a adopta practici de comunicare CSR (Responsabilitate Socială Corporatistă).

Un număr de alte proiecte comune cu privire la aspecte extrem de relevante pentru sector, cum ar fi dezvoltarea, în 2011, a unui Instrument on-line de evaluare a riscurilor pentru IMM-urile din sector (http://client.oiraproject.eu) sau abordarea Transparenţei şi Trasabilităţii lanţului de aprovizionare (2012) completează gama de activităţi ale partenerilor sociali din industria europeană de pielărie.

\section{Activităţi de formare}

Resursele umane fiind esenţiale pentru competitivitatea sectorului, toate tăbăcăriile europene înţeleg importanţa formării forţei lor de muncă. Pentru a concura pe piaţa internaţională în privinţa calităţii, continuitatea şi performanţa produsului, modă şi serviciile pentru clienţi, personalul calificat este esenţial, în special în economiile cu cost ridicat, cum este Europa. Combinaţia de experienţă şi tinereţe, adică muncitori calificaţi şi tineri angajaţi, reprezintă atuul-cheie pe care se bazează competitivitatea sectorului. Acest lucru poate fi îmbunătăţit la nivel de sector prin dezvoltarea formării profesionale continue şi învăţarea pe tot parcursul vieţii.

În ciuda unei tradiţii îndelungate şi reputaţiei internaţionale a şcolilor europene de pielărie, a departamentelor şi catedrelor universitare specializate, educaţia şi formarea profesională specifică domeniului pielăriei din Europa sunt în pericol. O masă critică de cursanţi, răspândirea geografică a tăbăcăriilor şi barierele lingvistice sunt doar câteva dintre obstacolele 
reorganisation of professional training in the European leather sector.

Continuing Vocational Training and life-long learning are promising instruments. Skills can be transferred or up-graded in the tanneries themselves with courses adapted to the specific job and coaching or learning at the trainee's own speed.

Training may be prescribed by law or by national labour agreements (e.g. regarding health and safety at work).

Over the last two years, tanneries across Europe have organised in-house and external training courses on: Leather technology; Fashion and trends; Environmental management systems; Health and safety at the workplace; Risk assessment; Factory wide Environmental briefings on actions, costs etc.

The Social Partners of the European Tanning industry, COTANCE and IndustriAll-European Trade Union, have been addressing the strategic issue of education and training in the leather sector in their Social Dialogue since the 1990s. Their efforts have led to the recent foundation of a EUROPEAN SECTOR SKILLS COUNCIL ON EMPLOYMENT AND TRAINING from where they steer the restructuring process (europeanskillscouncil.t-c-I.eu).

\section{ENVIRONMENTAL INDICATORS}

Environmental sustainability of leather production is essentially based on three pillars: raw materials processed, process efficiency, pollution prevention and control.

With regard to raw materials, $99 \%$ of the hides and skins processed by European tanneries derive from animals that have been raised primarily for other economic purposes (wool, milk and/or meat production). Raw hides and skins are therefore "renewable by-products" that are recovered and transformed, through a complex sequence of chemical and mechanical operations, into a high value added intermediate material for a number of strategic industries. In this context, finished leather represents a natural and renewable alternative to oil based products that are used for the same purposes.

The present section of the report focuses on the description of a set of reference indicators summarising the environmental performance of European tanneries. Achievements in this area by the sector are the result of investments in both process technologies (improvement care trebuie înlăturate printr-o reorganizare eficientă a formării profesionale în sectorul european de pielărie.

Formarea profesională continuă şi învăţarea pe tot parcursul vieţii sunt instrumente promiţătoare. Competenţele pot fi transferate sau perfecţionate chiar în tăbăcării prin cursuri adaptate la posturile specifice şi prin asistenţă sau învăţare în ritmul cursantului.

Formarea poate fi prescrisă prin lege sau prin acorduri naţionale de muncă (de exemplu, privind sănătatea şi siguranţa la locul de muncă).

În ultimii doi ani, tăbăcăriile din Europa au organizat, la sediul propriu sau în afara acestuia, cursuri de instruire privind: Tehnologia pielii; Modă şi tendinţe; Sisteme de management de mediu; Sănătatea şi siguranţa la locul de muncă; Evaluarea riscurilor; Informări de mediu la nivel de fabrică cu privire la acţiuni, costuri etc.

Partenerii sociali din industria europeană de pielărie, COTANCE şi Federaţia Sindicală Europeană IndustriAll, au abordat problema strategică a educaţiei şi formării în sectorul pielăriei în cadrul dialogului social încă din anii 1990. Eforturile lor au dus la fondarea recentă a unui CONSILIU SECTORIAL EUROPEAN AL COMPETENTELOR PRIVIND LOCURILE DE MUNCĂ ŞI FORMAREA prin intermediul căruia coordonează procesul de restructurare (europeanskillscouncil.t-c-l.eu).

\section{INDICATORI DE MEDIU}

Sustenabilitatea ecologică a producţiei de piele se bazează în mod esenţial pe trei factori: materiile prime prelucrate, eficienţa procesului, prevenirea şi controlul poluării.

Cu privire la materiile prime, $99 \%$ din pieile brute prelucrate de tăbăcăriile europene provin de la animale care au fost crescute în principal în alte scopuri economice (lână, lapte şi/sau producţie de carne). Prin urmare, pieile brute sunt "produse secundare regenerabile" care sunt recuperate şi transformate, printr-o secvenţă complexă de operaţii chimice şi mecanice, într-un material intermediar cu valoare adăugată mare pentru o serie de industrii strategice. În acest context, pielea finită reprezintă o alternativă naturală şi regenerabilă pentru produsele pe bază de petrol care sunt utilizate în aceleaşi scopuri.

Această secţiune a raportului se concentrează pe descrierea unui set de indicatori de referinţă care rezumă performanța de mediu a tăbăcăriilor europene. Realizările sectorului în acest domeniu reprezintă atât rezultatele investiţiilor în tehnologiile de proces 
through process efficiency and process innovation) and in End-of-Pipe technologies (improvement through treatment of outflows, such as wastewater).

The definition of environmental expenditure adopted in the present report corresponds to the one proposed by Eurostat: "any expense incurred to implement an action whose main (direct or indirect) objective is to manage and protect the environment, that is an action deliberately and principally aimed at preventing, reducing or removing the environmental degradation caused by any production and consumption activities".

\section{Consumption of Chemicals}

Chemical auxiliaries are used in numerous processes of leather manufacturing. The interaction between chemicals and the dermis (hide or skin substrate) is needed to eliminate non-required substances and to modify the structure and mobility of the collagen fibres, in order to provide the final leather with the required physical characteristics, including its final appearance. Chemicals in tanneries are normally used either in an aqueous medium or sprayed onto the leather surface. Chemical product research and process development have been constantly evolving towards substitution of dangerous chemicals, reducing exposure at the workplace and improved occupational health and safety, process efficiency, higher exhaustion of processing baths and reduction of releases of spent chemicals into the natural environment. (îmbunătăţire prin eficienţa şi inovarea procesului) cât şi în tehnologiile de depoluare (îmbunătăţire prin tratarea ieşirilor, cum ar fi apele reziduale).

Definiţia cheltuielilor de mediu adoptată în prezentul raport corespunde cu cea propusă de către Eurostat: "orice cheltuială suportată pentru punerea în aplicare a unei acţiuni al cărei obiectiv principal (direct sau indirect) este de a gestiona şi de a proteja mediul înconjurător, acţiune care vizează în mod deliberat şi în principal prevenirea, reducerea sau eliminarea degradării mediului cauzate de orice activitate de producţie şi de consum".

\section{Consumul de substanţe chimice}

Auxiliarii chimici sunt utilizaţi în numeroase procese de fabricare a pielii. Interacţiunea dintre substanţele chimice şi dermă (substratul pielii) este necesară pentru a elimina substanţele inutile şi pentru a modifica structura şi mobilitatea fibrelor de colagen, în scopul de a conferi pielii finite caracteristicile fizice necesare, inclusiv aspectul său final. Substanţele chimice sunt utilizate în mod normal în tăbăcării fie într-un mediu apos (în flotă), fie prin pulverizare pe suprafaţa pielii. Cercetarea produselor chimice şi dezvoltarea proceselor au evoluat continuu spre substituirea chimicalelor periculoase, reducerea expunerii la locul de muncă şi îmbunătăţirea sănătăţii şi securităţii ocupaţionale, eficientizarea proceselor, epuizarea mai mare a flotelor de prelucrare şi reducerea emisiilor de substanţe chimice reziduale în mediul natural.

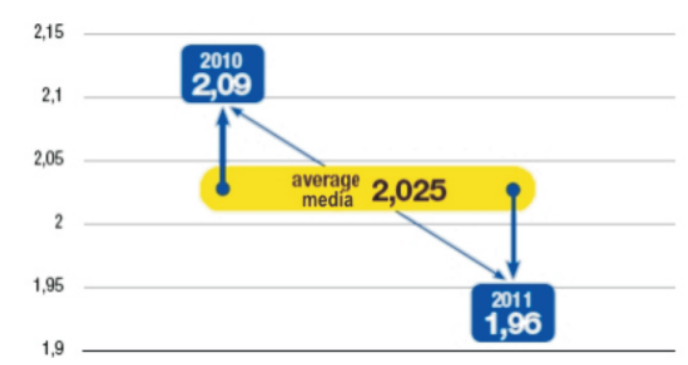

Figure 16. Chemicals consumption $\left(\mathrm{kg} / \mathrm{m}^{2}\right)$

Figura 16. Consum de substanţe chimice $\left(\mathrm{kg} / \mathrm{m}^{2}\right)$

Data collected by national associations show an average value of $2.02 \mathrm{~kg}$ of chemicals per $\mathrm{m}^{2}$ of finished leather over the 2010-2011 period. Reduction of the intensity of process chemicals, as well as an increase of eco-compatibility of auxiliaries are achieved through continuous experimentation and through the cooperation of tannery technicians with chemicals and machinery suppliers.
Datele colectate de către asociaţiile naţionale indică un consum mediu de $2,02 \mathrm{~kg}$ de produse chimice pe $\mathrm{m}^{2}$ de piele finită în perioada 2010-2011. Reducerea impactului chimicalelor de proces, precum şi creşterea eco-compatibilităţii auxiliarilor sunt realizate prin experimentare continuă şi prin cooperarea tehnicienilor din tăbăcării cu furnizorii de substanţe chimice şi utilaje. 
So, the chemical consumption per product unit decreased $6.2 \%$ between 2010 and 2011 .

\section{Energy Consumption}

Electricity is mostly used in tanneries to operate machinery and vessels, to produce compressed air and for lighting. Thermal energy is needed for drying leather in different process phases, to heat water to temperatures needed for chemical processes, and to control the temperature of the working environment. Significant factors influencing energy consumption in a tannery are the type of raw materials entering the tannery and the energy intensity of the different process phases carried out.

To calculate the overall consumption per product unit, data have been expressed in Tonnes of Oil Equivalent per 1,000 square metre of leather produced $\left(T O E / 1,000 \mathrm{~m}^{2}\right)$. The amalgamation of data provided by national associations gave an average value of 2.0 TOE/1,000 $\mathrm{m}^{2}$ for the $2010-2011$ period (Figure 17). Reducing energy consumption in tanneries mainly implies installing highly energyefficient machinery and developing energy-saving processes. Analysing the breakdown of energy consumption (Figure 18), electricity is close to $50 \%$ of total energy used, in both 2010 and in 2011. Thermal energy comes mainly from the combustion of natural gas (methane) and/or other fossil fuels (fuel oil, LP gas, others). An increasing number of tanneries are investing in renewable energy resources.

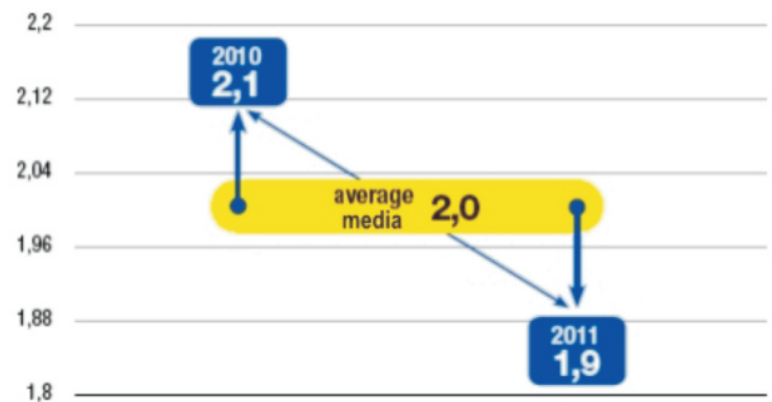

Figure 17. Energy consumption

per product unit 2010-2011 (TOE/1000 m²)

Figura 17. Consum de energie

pe unitate de produs 2010-2011 (TEP/1000 $\left.\mathrm{m}^{2}\right)$

COTANCE, together with other 15 European partners, is implementing a project named IND - ECO
Aşadar, consumul de substanţe chimice pe unitate de produs a scăzut cu 6,2\% între 2010 şi 2011.

\section{Consumul de energie}

Electricitatea se utilizează în tăbăcării pentru a putea opera utilajele şi echipamentele, pentru a produce aer comprimat şi pentru iluminare. Energia termică este necesară pentru uscarea pielii în diferite faze ale procesului tehnologic, pentru a încălzi apa la temperaturile necesare pentru procesele chimice şi pentru a controla temperatura mediului de lucru. Factorii semnificativi care influenţează consumul de energie într-o tăbăcărie sunt tipul de materii prime care intră în tăbăcărie şi intensitatea energiei utilizate în diferitele faze ale procesului.

Pentru a calcula consumul total pe unitate de produs, datele s-au transpus în Tone Echivalent Petrol pe 1000 metri pătraţi de piele produsă (TEP/1000 m²). Combinarea datelor furnizate de asociaţiile naţionale a dat o valoare medie de $2,0 \mathrm{TEP} / 1000 \mathrm{~m}^{2}$ pentru perioada 2010-2011 (Figura 17). Reducerea consumului de energie în tăbăcării presupune în principal instalarea unor maşini extrem de eficiente energetic şi dezvoltarea unor procese care economisesc energie. Analizând consumul energetic defalcat pe surse (Figura 18), se constată că electricitatea reprezintă aproape $50 \%$ din energia totală utilizată în 2010 şi 2011. Energia termică provine în principal din arderea gazului natural (metan) şi/sau a altor combustibili fosili (păcură, gaz petrolier lichefiat, altele). Un număr tot mai mare de tăbăcării investesc în resurse de energie regenerabilă.

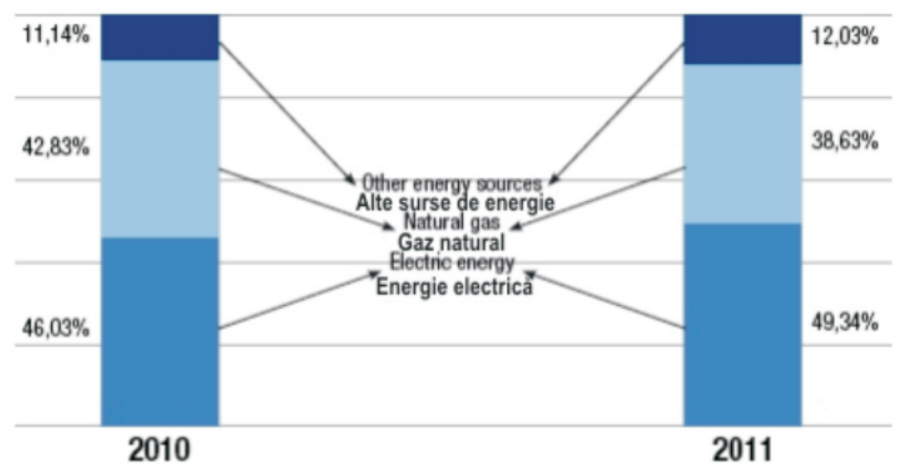

Figure 18. Energy consumption breakdown 2010-2011 (\%)

Figura 18. Defalcare consum energetic 2010-2011 (\%)

COTANCE, împreună cu alţi 15 parteneri europeni, implementează proiectul IND - ECO "Alianţa 
"Industry Alliance for reducing energy consumption and $\mathrm{CO} 2$ emissions" sponsored by the European Commission (EACl Agency) within "Intelligent Energy Europe". The project started in May 2012 and will last for 3 years. It is aimed at developing the best framework conditions for supporting tanners and footwear manufacturers to invest in energy efficiency (www.ind-ecoefficiency.eu).

\section{Water Consumption and Discharge}

Water serves as a medium for fundamental process phases, for example tanning and dyeing, which all occur in drums and other vessels through dissolved chemicals. Water is also used to wash leather, machinery and the workplace. The most important water sources are represented by authorised and regulated artesian wells located within the tannery site and industrial and civil aqueducts. Water supply and wastewater treatment represent the most important environmental aspects of the tanning industry.

As shown in Figure 19, water consumption per product unit averages $0.13 \mathrm{~m}^{3} / \mathrm{m}^{2}$. The reduction of water consumption per product unit has been an environmental priority for European tanneries over the years. This has been possible mainly through the setting of continuous improvement objectives aiming at developing water efficient processes and water recycling technologies. Almost $95 \%$ of the water used in tanneries is subsequently discharged; the remaining share is represented mostly by water that evaporates during manufacturing or the moisture content of waste sent to recycling and/or disposal.

The water discharged is then sent for purification. Unlike some non-European competitor countries, where environmental legislation is either lacking or poorly enforced, $100 \%$ of European tanneries treat their wastewaters through complete and complex purification systems.

The majority of leather production in south European countries is concentrated in tanning districts. Here, centralised effluent treatment plants have been built and improved over the years. Centralised water purification plants managed by district consortia are an excellent international example of inter-corporate collaboration for environmental sustainability. In this context, tanneries normally carry out only primary treatment within their facilities, delegating to the centralised effluent treatment plants the other necessary physical, chemical and biological treatments.

In territories where tanning districts are located, the same effluent treatment plants, originally created industrială pentru reducerea consumului energetic şi al emisiilor de $\mathrm{CO}_{2}{ }^{\prime \prime}$, finanţat de către Comisia Europeană (Agenţia EACl) în cadrul Programului "Intelligent Energy Europe". Proiectul a început în mai 2012 şi va dura 3 ani. Se urmăreşte dezvoltarea celor mai bune condiţii-cadru pentru sprijinirea tăbăcarilor şi producătorilor de încălţăminte să investească în eficienţa energetică (www.ind-ecoefficiency.eu).

\section{Consumul şi deversarea de apă}

Apa serveşte ca mediu de lucru pentru fazele de bază ale procesului de prelucrare piei, de exemplu, tăbăcirea şi vopsirea, se desfăşoară în butoaie şi alte echipamente care utilizează flote în care sunt dizolvate produsele chimice. Apa este, de asemenea, utilizată pentru a curăţa pielea, maşinile şi locul de muncă. Cele mai importante surse de apă sunt reprezentate de puţuri autorizate şi reglementate situate în tăbăcărie şi apeducte industriale şi civile. Alimentarea cu apă şi tratarea apelor uzate reprezintă cele mai importante aspecte de mediuale industriei de pielărie.

După cum arată Figura 19, consumul de apă pe unitatea de produs este în medie de $0,13 \mathrm{~m}^{3} / \mathrm{m}^{2}$. Reducerea consumului de apă pe unitatea de produs a fost, de-a lungul anilor, o prioritate de mediu pentru tăbăcăriile europene. Acest lucru a fost posibil în principal prin stabilirea unor obiective de îmbunătăţire continuă care vizează dezvoltarea proceselor de utilizare eficientă a apei şi tehnologiilor de reciclare a apei. Aproape $95 \%$ din apa folosită în tăbăcării este ulterior evacuată; restul reprezintă în mare parte apă care se evaporă în timpul fabricării sau conţinutul de umiditate al deşeurilor trimise la reciclare şi/sau eliminate.

Apa reziduală deversată este trimisă apoi spre purificare. Spre deosebire de unele ţări concurente non-europene, în care legislaţia de mediu este prost aplicată sau lipseşte, 100\% din tăbăcăriile europene îşi tratează apele reziduale utilizând sisteme de purificare complete şi complexe.

În ţările din sudul Europei majoritatea producţiei de piele este concentrată în districte. Aici s-au construit instalaţii centralizate de tratare a apelor reziduale, acestea fiind îmbunătăţite permanent de-a lungul vremii. Instalaţiile centralizate de purificare a apelor reziduale gestionate de consorţiile districtelor sunt un exemplu excelent la nivel internaţional de colaborare inter-corporatistă pentru sustenabilitate ecologică. În acest context, în mod normal, în cadrul tăbăcăriilor se efectuează doar tratamente primare, delegând celelalte tratamente fizice, chimice şi biologice instalaţiilor centralizate de tratare a efluenţilor.

În teritoriile în care sunt situate districtele de tăbăcării, aceleaşi instalaţii de tratare a efluenţilor, 
to serve the industry, have evolved over the years and nowadays also contribute significantly to the purification of civil wastewater.

Tanneries located outside industrial districts carry out wastewater purification independently, and discharge their treated effluent mostly to public sewage systems.

Tanning wastewater quality is mainly monitored by analysing 8 parameters: Total Suspended Solids (TSS); Chemical Oxygen Demand (COD); Sulphates $\left(\mathrm{SO}_{4}{ }^{\prime}\right)$; Nitrogen; Chlorides (Cl-); Chrome (III); Sulphides ( $\mathrm{S}^{*}$ ).

Figure 20 shows the data of average wastewater purification efficiency of the different effluent treatment systems distributed in the countries that contributed to the survey, for each of the described parameters. Purification efficiency in this case is expressed as:

create iniţial pentru a deservi industria, au evoluat permanent şi în zilele noastre contribuie în mod semnificativ şi la purificarea apelor uzate civile.

Tăbăcăriile situate în afara districtelor industriale efectuează purificarea apelor uzate în mod independent şi deversează efluenţii trataţi în mare parte în sistemele publice de canalizare.

Calitatea apelor reziduale de la tăbăcării este în principal monitorizată analizând 8 parametri: solide totale în suspensie (TSS); consumul chimic de oxigen (CCO); sulfaţi $\left(\mathrm{SO}_{4}{ }^{\prime}\right)$; azot; $\operatorname{cloruri}(\mathrm{Cl})$; $\operatorname{crom}(\mathrm{III})$; sulfuri $\left(\mathrm{S}^{-}\right)$.

Figura 20 prezintă datele privind eficienţa purificării apelor reziduale a diferitelor sisteme de tratare a efluenţilor din ţările care au contribuit la studiu, pentru fiecare parametru descris. În acest caz, eficienţa purificării este exprimată după cum urmează:

$$
([\mathrm{IN}]-[\mathrm{OUT}]) /[\mathrm{IN}]
$$

where [IN] is the concentration of the parameter in the inflow of the effluent treatment plant, and [OUT] is the concentration of the same parameter in the wastewater discharged after treatment. This indicator ultimately measures the capacity of the adopted system to remove pollutants from water. As is evident, the various effluent treatment systems adopted in European tanneries, guarantee excellent purification performances for almost all parameters, with the exception of dissolved salts, representing an unsolved technological problem at international level.

Minimisation of water pollution has been achieved in European tanneries through the development and implementation of processintegrated techniques, aimed at reducing the chemical content in wastewater, either by modifying chemical dosage, or by favouring high exhaustion of baths.

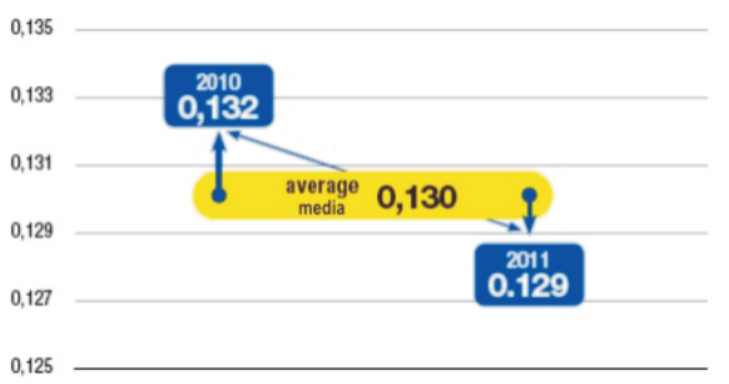

Figure 19. Water consumption per product unit $2010-2011\left(\mathrm{~m}^{3} / \mathrm{m}^{2}\right)$

Figura 19. Consum de apă pe unitate de produs $2010-2011\left(\mathrm{~m}^{3} / \mathrm{m}^{2}\right)$ unde [IN] este concentraţia parametrului la intrarea în instalaţia de tratare a efluenţilor, iar [OUT] este concentraţia aceluiaşi parametru în apele uzate evacuate după tratament. Acest indicator măsoară capacitatea sistemului de tratare adoptat de a elimina poluanţii din apă. În mod evident, diferitele sisteme de tratare a efluenţilor adoptate în tăbăcăriile europene garantează performanţe excelente de purificare pentru aproape toţi parametrii, cu excepţia sărurilor dizolvate, care reprezintă o problemă tehnologică nerezolvată la nivel internaţional.

Reducerea poluării apei s-a realizat în tăbăcăriile europene prin dezvoltarea şi implementarea unor tehnici integrate în proces, care au scopul de a reduce conţinutul de substanţe chimice în apele uzate fie prin modificarea cantităţii de chimicale dozată, fie prin favorizarea unei epuizări mai mari a flotelor.

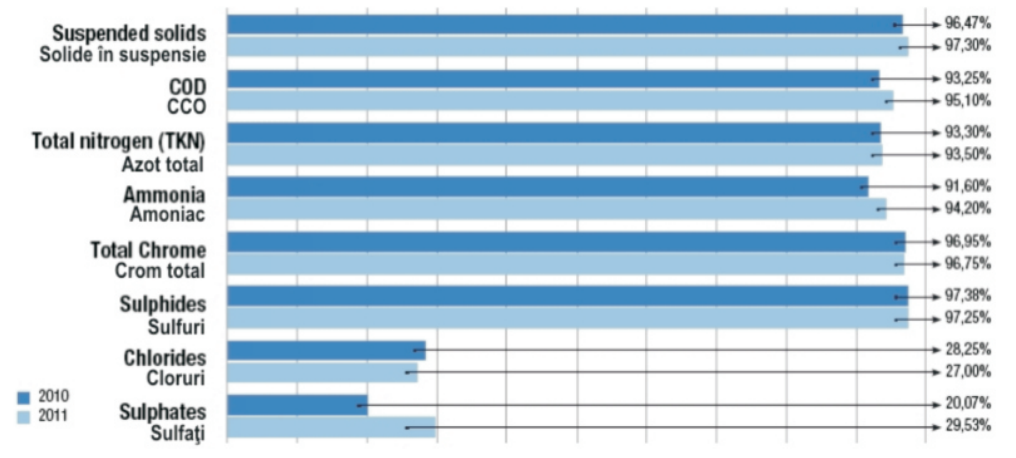

Figure 20. Wastewater purification efficiency 2010-2011 (\%)

Figura 20. Eficienţa purificării apelor uzate 2010-2011 (\%) 


\section{Waste Management}

As shown in Figure 21, European tanneries produce, on average, 2.14 kilograms of waste for every square metre produced. This figure might apparently represent an environmentally significant value, but the overall management and final destination of tanning wastes have to be taken into due consideration.

The weight of fully processed bovine grain side leather represents only approximately $20-25 \%$ of the weight of the raw hides entering the tannery. Some tanneries produce and market co-products (such as splits) as lower specification leathers. In other cases, by-products or wastes deriving from the tanning process are used as raw material for other production processes. Only a very small portion of the residues directly deriving from raw hides and skins do not find a second use. Other typical wastes of tanneries (such as sludge generated during wastewater purification treatments) have been mainly dumped in the past, although alternative technologies are emerging nowadays. The European Waste Catalogue (EWC) offers an accurate classification of waste deriving from tanning operations: 0401 wastes from the leather industry (with 10 subcategories).

By-products, residual material, and wastes are collected and stored separately in European tanneries. Some national cases show that the portion of material collected and stored separately is highly significant ( $98 \%$ for Italy). The separate collection and storage helps to preserve the technical characteristics of different materials and, as a consequence, favours reuse and recycling. Apart from separate collection and storage of various residual materials, waste management activities in tanneries include the identification and selection of specific waste disposal routes and/or specialised companies, with the aim of reusing and/or recycling the secondary raw materials produced. A number of factors contribute to the technical-economic possibility of recycling the byproducts or waste produced, depending on the tannery's internal organisation, but also on the local availability of treatment or disposal facilities. Optimised "waste supply chains" can lead to as much as $75 \%$ of waste produced being sent for recycling.

\section{Gestiunea deşeurilor}

După cum arată Figura 21, tăbăcăriile europene produc, în medie, 2,14 kilograme de deşeuri pentru fiecare metru pătrat de piele produsă. Această cifră ar putea reprezenta o valoare aparent semnificativă pentru mediu, însă trebuie să se ia în considerare şi managementul general, şi destinaţia finală a deşeurilor de la tăbăcării.

Greutatea pieilor bovine prelucrate ca piei feţe reprezintă doar aproximativ $20-25 \%$ din greutatea pieilor brute care intră în tăbăcărie. Unele tăbăcării produc şi comercializează produse secundare (cum ar fi şpalturi) ca piei cu specificaţii reduse. În alte cazuri, produsele secundare sau deşeurile provenite din procesul de tăbăcire sunt folosite ca materie primă pentru alte procese de producţie. Numai o mică parte din reziduurile ce derivă direct din pieile brute nu au o utilizare secundară. Alte deşeuri tipice din tăbăcării (ex.: nămolurile generate în timpul tratamentelor de epurare a apelor uzate) au fost în principal depozitate la groapa de gunoi în trecut, dar astăzi sunt dezvoltate tehnologiile alternative. Catalogul European de Deşeuri (CED) oferă o clasificare corectă a deşeurilor provenite din operaţiile de prelucrare a pieilor: 0401 deşeuri din industria de pielărie (cu 10 subcategorii).

Produsele secundare, materialele reziduale şi deşeurile sunt colectate şi depozitate separat în tăbăcăriile europene. Unele cazuri naţionale arată că proporţia de materiale colectate şi depozitate separat este foarte mare (98\% pentru Italia). Colectarea şi depozitarea separată ajută la păstrarea caracteristicilor tehnice ale diferitelor materiale şi, în consecinţă, favorizează reutilizarea şi reciclarea. În afară de colectarea şi depozitarea separată a diferitelor materiale reziduale, activităţile de gestionare a deşeurilor din tăbăcării includ identificarea şi selectarea rutelor specifice şi/sau a firmelor specializate de eliminare a deşeurilor, cu scopul de a reutiliza şi/sau recicla materiile secundare produse. O serie de factori contribuie la posibilitatea tehnico-economică de reciclare a produselor secundare sau a deşeurilor produse, în funcţie de organizarea internă a tăbăcăriei, dar şi de disponibilitatea la nivel local a instalaţiilor de tratare sau de eliminare. "Lanţurile de aprovizionare cu deşeuri" optimizate pot conduce la reciclarea a până la $75 \%$ din deşeurile rezultate. 


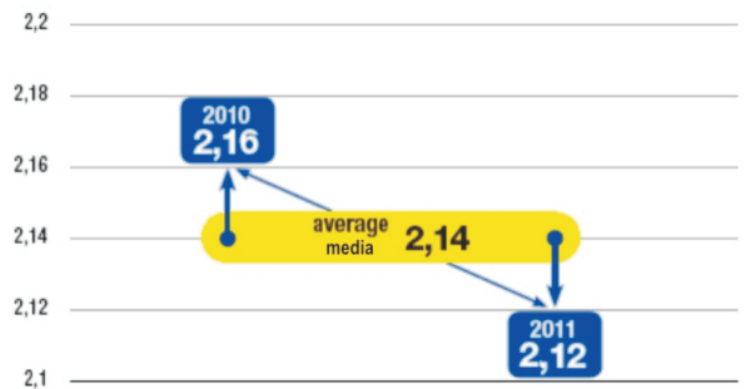

Figure 21. Waste production per product unit 2010-2011 (kg/m²)

Figura 21. Deşeuri generate pe unitate de produs $2010-2011\left(\mathrm{~kg} / \mathrm{m}^{2}\right)$

\section{Air Emissions}

The main parameters affecting air quality in tanneries are Volatile Organic Compounds (VOC), Dust and Hydrogen Sulphide. Moreover, the thermal systems used to generate heat release a number of pollutants during combustion, namely Nitrogen Oxides (NOx), Sulphur Oxides (SOx), and, of course, Carbon Dioxide $\left(\mathrm{CO}_{2}\right)$. On this latter parameter, innovative and very interesting sectoral approaches on Carbon footprint have been described in a technical report produced by UNIDO ("Leather Carbon Footprint: finally a harmonised approach?").

For emissions to the air, data provided by national associations on the consumption of organic solvents per product unit have been elaborated at European level. In Figure 23 it is shown how average data $\left(43.36 \mathrm{~g} / \mathrm{m}^{2}\right)$ does not differ very much from 2010 and 2011 annual values. Moreover, Figure 23 shows the evolution of solvent consumption compared to production in Arzignano, the biggest tanning district in Europe over the period 1996/2011. The trend for solvent consumption has been decreasing (-72\%) from 1996 to 2011, as compared to the output rates shown in the figure.

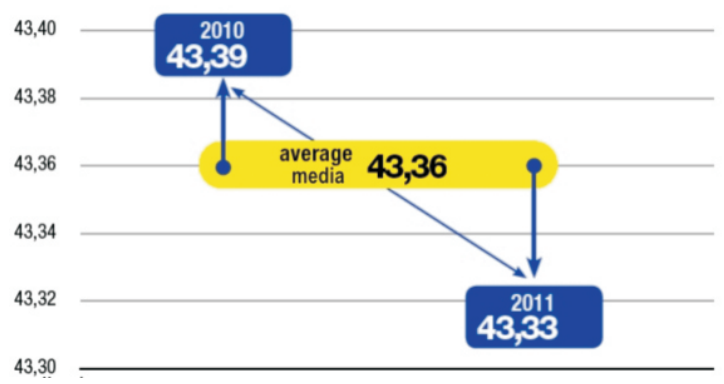

Figure 22. Solvents consumption per product unit 2010-2011 (g/m $\left.{ }^{2}\right)$

Figura 22. Consum de solvenţi pe unitate de produs $2010-2011\left(\mathrm{~g} / \mathrm{m}^{2}\right)$

\section{Emisii în aer}

Principalii parametri care afectează calitatea aerului în tăbăcării sunt compuşii organici volatili (COV), praful şi hidrogenul sulfurat. Mai mult decât atât, sistemele termice folosite pentru a genera căldură emit o serie de poluanţi în timpul arderii, şi anume oxizi de azot (NOx), oxizi de sulf (SOx) şi, desigur, dioxid de carbon $\left(\mathrm{CO}_{2}\right)$. În privinţa parametrului din urmă, abordări sectoriale inovatoare şi foarte interesante privind amprenta de carbon au fost descrise într-un raport tehnic elaborat de UNIDO ("Leather Carbon Footprint: finally a harmonised approach?").

Emisiile în aer au fost elaborate pe baza datelor furnizate de asociaţiile naţionale privind consumul de solvenţi organici pe unitatea de produs. Figura 23 prezintă valoarea medie $\left(43,36 \mathrm{~g} / \mathrm{m}^{2}\right)$ care nu diferă foarte mult de valorile anuale din 2010 şi 2011. Mai mult decât atât, Figura 23 prezintă evoluţia consumului de solvenţi, comparativ cu volumul de producţie în Arzignano, cel mai mare district de tăbăcării din Europa în perioada 1996-2011. Tendinţa de consum de solvent a fost în scădere (-72\%) din 1996 până în 2011, în comparaţie cu ratele de ieşire prezentate în figură.

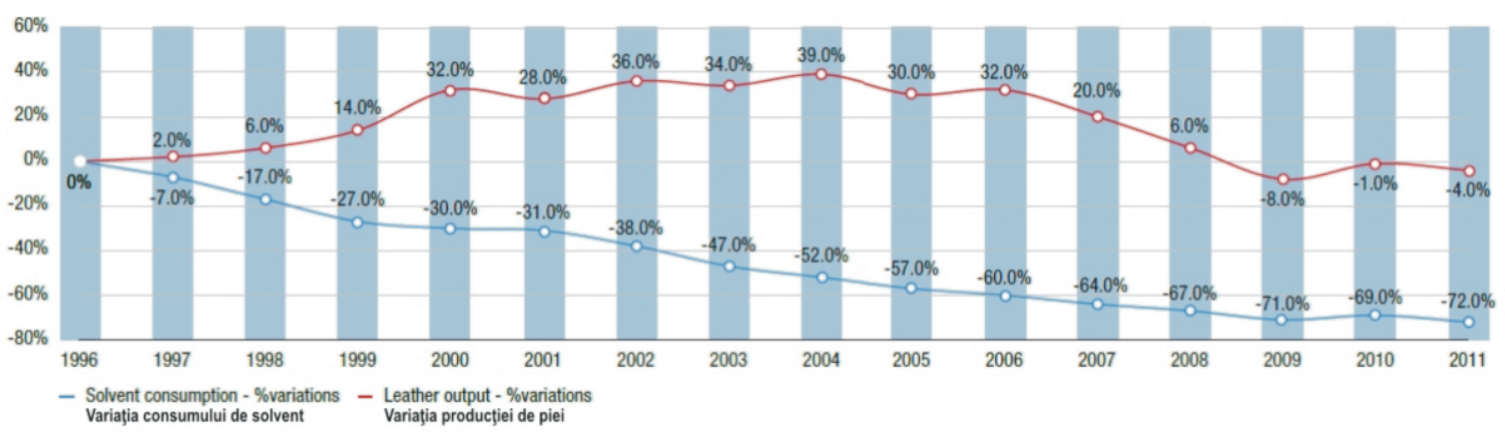

Figure 23. Solvent consumption compared with production 1996-2011 (\%)

Figura 23. Consum de solvenţi în comparaţie cu volumul de producţie 1996-2011 (\%) 


\section{Environmental Costs}

The environmental expenditures are defined in the present document in accordance with Eurostat; these are "expenses incurred to implement an action whose main objective is to manage and protect the environment...". Associations contributing to the realisation of this report, through direct interaction with tanneries and other structures involved in the environmental supply chain (such as centralised effluent treatment plants and waste management operators) have been able to collect, evaluate, estimate and organise these data. In European tanneries, the proportion of environmental expenditures of turnover amounts to $4.3 \%$ (Figure 24). The indicator increased by over $4 \%$ in one year. Considering the fact that common values of industrial margins (EBDTA) for tanning businesses seldom exceed $5 \%$, the importance and magnitude of the effort towards environmental protection expended by European tanners, and the impact on their international competitiveness versus non-European tanneries become evident. This unbalanced playing field provides unfair and unethical comparative advantages to certain international competitors who follow much less sustainable industrial practices. If this issue is not adequately addressed, it will continue producing negative effects on the planet and on the European Leather sector that is engaged in producing wealth, jobs and progress, demonstrating virtuous conduct from an environmental point of view. Environmental protection should be rewarded rather than discouraged with policies that allow "hiding the dust under the carpet" in distant countries.

Expenses linked to good water management represent almost $60 \%$ of total environmental costs in Europe's tanneries. Activities for minimising water consumption and purifying wastewater include the development of effective water-saving techniques or sophisticated float recycling processes (carried out mainly by specialised tanning technicians, in cooperation with chemical companies and machine manufacturers), the management and maintenance of in-house purification systems, and compliance testing and monitoring. One very important cost item, for tanneries that delegate some phases of the water purification process, is represented by the cost of the external effluent treatment service.

The costs related to specialised services of waste collection, transport, recycling and/or disposal

\section{Costuri de mediu}

Cheltuielile de mediu sunt definite în prezentul document în conformitate cu Eurostat. Acestea reprezintă "orice cheltuială suportată pentru punerea în aplicare a unei acţiuni al cărei obiectiv principal este de a gestiona şi de a proteja mediul înconjurător...". Asociaţiile care contribuie la realizarea acestui raport, prin interacţiunea directă cu tăbăcăriile şi cu alte structuri implicate în lanţul de aprovizionare de mediu (cum ar fi instalaţii centralizate de tratare a efluenţilor şi operatorii care gestionează deşeurile) au reuşit să colecteze, să evalueze, să estimeze şi să organizeze aceste date. În tăbăcăriile europene, proporţia cheltuielilor de mediu din cifra de afaceri se ridică la $4,3 \%$ (Figura 24). Indicatorul a crescut cu peste $4 \%$ într-un an. Având în vedere faptul că valorile comune ale marjelor industriale (EBDTA) pentru tăbăcării depăşesc rar $5 \%$, importanţa şi amploarea efortului de proteç̧ie a mediului depus de tăbăcarii europeni, precum şi impactul asupra competitivităţii lor pe plan internaţional faţă de tăbăcăriile non-europene devin evidente. Acest dezechilibru oferă avantaje comparative inechitabile şi lipsite de etică anumitor concurenţi internaţionali care urmează practici industriale mult mai puţin sustenabile. Dacă această problemă nu este rezolvată în mod corespunzător, va continua să producă efecte negative asupra planetei şi asupra sectorului european de pielărie, care este implicat în realizarea de bunăstare, locuri de muncă şi progres, demonstrând un comportament virtuos din punctul de vedere al mediului. Protecţia mediului ar trebui să fie mai degrabă recompensată, decât descurajată cu politici care permit "ascunderea prafului sub covor" în ţări îndepărtate.

Cheltuielile legate de buna gestionare a apei reprezintă aproape $60 \%$ din costurile totale de mediu în tăbăcăriile europene. Activităţile pentru minimizarea consumului de apă şi epurarea apelor uzate includ dezvoltarea unor tehnici eficiente de economisire a apei sau procedee sofisticate de reciclare a flotelor (realizate în principal de către tehnicieni pielari specializaţi, în cooperare cu companiile chimice şi producătorii de utilaje), gestionarea şi întreţinerea sistemelor proprii de purificare, precum şi testarea conformităţii şi monitorizarea. Un element de cost foarte important, pentru tăbăcăriile care delegă anumite faze ale procesului de epurare a apei, este reprezentat de costul serviciilor externe de tratare a efluenţilor.

Costurile legate de serviciile specializate de colectare, transport, reciclare şi/sau eliminare a 
represent the largest share of environmental expenses related to solid waste management. Other activities carried out in tanneries representing significant environmental expenses are: separate collection of waste, management and maintenance of storage areas, waste testing and characterisation, administrative requirements related to waste management (Figure 25).

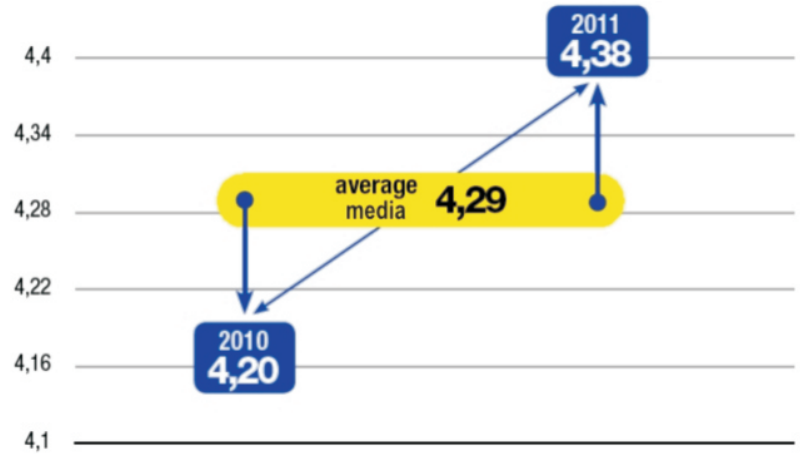

Figure 24. Incidence of environmental expenses on turnover 2010-2011 (\%)

Figura 24. Incidenţa cheltuielilor de mediu în cifra de afaceri 2010-2011 (\%)

European tanneries review continuously the efficiency of their production processes, perform audits and undertake research into new, more efficient technologies. One important aspect for tanneries (possibly leading to further environmental costs) is activity aimed at improving energy efficiency through, for example, adoption of less energy intensive techniques and greater use of renewable energy sources.

All managerial activities aiming at guaranteeing a constant improvement of corporate environmental performance - starting from full compliance with the legislation in force - are included in the "other costs" category.

Competition in the globalised leather market will be increasingly affected by the way stakeholders reward tanneries' environmental performances. All the efforts sustained in Europe over the years deserve to be valued more by public authorities and better incentivised through measures encouraging environmental investments and implementing tax credits in relation to the environmental expenses incurred. deşeurilor reprezintă cea mai mare parte a cheltuielilor de mediu referitoare la gestionarea deşeurilor solide. Alte activităţi desfăşurate în tăbăcării, reprezentând cheltuieli semnificative de mediu sunt: colectarea separată a deşeurilor, gestionarea şi întreţinerea zonelor de depozitare, testarea şi caracterizarea deşeurilor, cerinţele administrative legate de gestionarea deşeurilor (Figura 25).

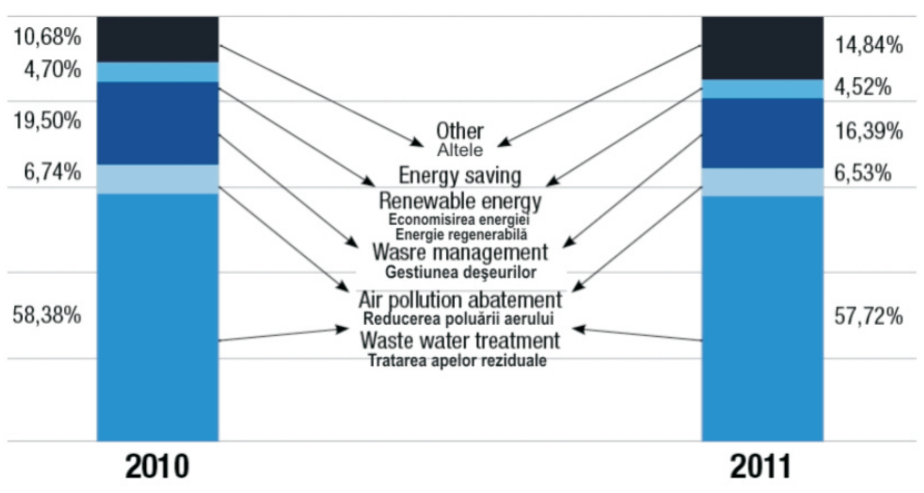

Figure 25. Distribution of environmental expenses 2010-2011 (\%)

Figura 25. Distribuţia cheltuielilor de mediu 2010-2011 (\%)

Tăbăcăriile europene analizează în mod continuu eficienţa proceselor lor de producţie, efectuează audituri şi desfăşoară cercetări în domeniul tehnologiilor noi, cu eficienţă crescută. Un aspect important pentru tăbăcării (care poate duce la costuri suplimentare de mediu) este activitatea care vizează îmbunătăţirea eficienţei energetice, de exemplu, prin adoptarea de tehnici care consumă mai puţină energie şi utilizarea pe scară mai largă a surselor de energie regenerabile.

Toate activităţile de gestionare care vizează garantarea unei îmbunătăţiri constante a performanţei de mediu a companiilor - începând de la deplina conformare cu legislaţia în vigoare - sunt incluse în categoria "alte costuri".

Concurenţa pe piaţa globalizată a pielii va fi tot mai afectată de modul în care părţile interesate recompensează performanţele de mediu ale tăbăcăriilor. Toate eforturile susţinute în Europa de-a lungul anilor merită o apreciere mai mare din partea autorităţilor publice, şi o mai bună stimulare prin măsuri de încurajare a investiţiilor de mediu şi punerea în aplicare a creditelor fiscale în ceea ce priveşte cheltuielile de mediu suportate. 


\section{PRIORITIES FOR SUSTAINABLE TANNING}

The information outlined below provides an indication of the priorities that the associations involved in the survey have identified, under the three key elements representing the sustainable development paradigm: Economic, Environmental, Social. The logical scheme is based on a method defined as "Gap Analysis". It allows identification of the factors that are strategic for the attainment of sectoral sustainable growth objectives and the gap between the performance of each individual factor considered under current circumstances and the optimum conditions that can be reached under the objectives set.

\section{Economic}

In general terms, from an economic point of view, the sustainable development of European tanneries can only be achieved by "Remaining competitive and ahead of competition". When raw materials typically represent some $50 \%$ of leather production costs and competitors in many third countries enjoy up to $40 \%$ lower prices of local hides and skins through the enforcement of unfair export restrictions, remaining competitive on the global market becomes almost a miracle. European tanneries are located in high cost countries, where all industrial costs are far higher than those in the most important non-European competitor countries. In this context, European leather production historically positioned itself at the top end of the market, constantly seeking to improve quality and to innovate its offer to the market. In order to achieve this goal and to remain present on the market there is a need for: Free and fair access to raw materials; Reciprocity in the access to leather markets; Improved access to finance; Research and technological development towards higher levels of efficiency; Innovation and support for the development of new products; Creating a customer and consumer demand for ethically produced, sustainable products with a low environmental impact; Effective solutions against "social and environmental dumping".

\section{Environmental}

At consumer level, tanning has not a brilliant reputation with regard to environmental protection. This perception contrasts with the technological progress of European tanneries towards environmental sustainability that the industry has undertaken in

\section{PRIORITĂTI PENTRU O INDUSTRIE DE PIELĂRIE DURABILĂ}

Informaţiile prezentate mai jos oferă o indicaţie a priorităţilor pe care le-au identificat asociaţiile implicate în studiu, în cadrul celor trei piloni cheie care reprezintă paradigma dezvoltării durabile: economic, ecologic, social. Schema logică se bazează pe o metodă definită ca "Analiza GAP". Aceasta permite identificarea factorilor care sunt strategici pentru atingerea obiectivelor sectoriale de dezvoltare durabilă şi diferența dintre performanța individuală a fiecărui factor luat în considerare în circumstanţele actuale şi condiţiile optime care pot fi atinse prin obiectivele stabilite.

\section{Economic}

În termeni generali, din punct de vedere economic, dezvoltarea durabilă a tăbăcăriilor europene poate fi realizată numai "rămânând competitivi şi cu un pas înaintea concurenţei". Atunci când materiile prime reprezintă de obicei aproximativ $50 \%$ din costurile de producţie a pielii, iar concurenţii din multe ţări terţe se bucură de preţuri cu până la $40 \%$ mai mici la pieile brute locale prin aplicarea restricţiilor neechitabile la export, să rămâi competitiv pe piaţa mondială este aproape un miracol. Tăbăcăriile europene sunt situate în ţări cu costuri ridicate, unde toate costurile industriale sunt mult mai mari decât în cele mai importante ţări concurente non-europene. În acest context, producţia europeană de piele s-a situat, din punct de vedere istoric la vârful pieţei, căutând în permanenţă să îmbunătăţească calitatea şi să lanseze oferte inovatoare pe piaţă. Pentru a atinge acest obiectiv şi pentru a rămâne prezentă pe piaţă sunt necesare: accesul liber şi echitabil la materii prime; reciprocitate în accesul la pieţele de piele; acces mai bun la finanţare; cercetare şi dezvoltare tehnologică orientate spre eficienţă înaltă; inovare şi sprijin pentru dezvoltarea de produse noi; crearea, în rândul clienţilor şi consumatorilor, a cererii pentru produse sustenabile fabricate conform unor norme etice, cu impact redus asupra mediului; soluţii eficiente împotriva "dumping-ului social şi de mediu".

\section{Ecologic}

La nivel de consumator, tăbăcirea nu are o reputaţie strălucită în ceea ce priveşte protecţia mediului. Această percepţie este în contrast cu progresul tehnologic al tăbăcăriilor europene spre durabilitate ecologică, pe care I-a abordat industria în vremurile 
modern times. Environmental improvements have been deployed mainly to guarantee compatibility of industrial production with civic requirements in the communities where tanneries were present but are becoming increasingly important as a marketing tool aimed at orientating consumers' purchasing decisions. In particular, the last 50 years, European tanners have produced astonishing environmental achievements, through active cooperation of all the actors in the technological supply chain. Tanneries of today consume less water, less energy and have substituted dangerous chemicals. They treat their wastewater efficiently and recover and recycle most of their organic waste. Further technological development, combined with innovation in environmental communication and harmonisation of international standards on product environmental footprint rules are necessary to guarantee the sustainable development of tanneries in general and the European sector in particular. Some key priorities identified are therefore linked with environmental footprinting, with process techniques and with end of pipe technologies: Identification of appropriate and harmonised methodologies regarding Life Cycle Assessment-Carbon/Water Footprint; Implementation, as appropriate, of Ecodesign within the whole leather value chain; Optimisation of water use and wastewater management; Improved levels of energy efficiency; Waste minimisation through increased reuse and recycling of by-products; Standards and regulations rewarding environmental performance.

\section{Social}

Under the aspect of the Social pillar of sustainability, the tanning industry, again, has different "stakeholder specific" implications, leading to various development strategies. Local communities, social and environmental NGOs, workers and their trade unions, pupils, students and apprentices, are examples of stakeholders that interact with tanneries and can have an impact on their development. When tanneries are aggregated in industrial districts (as it is the case for the majority of companies in southern Europe), the wealth of the territories mostly depends on leather. Recent multi-stakeholder engagement experiences have shown their effectiveness in identifying dialogue platforms to discuss social (and environmental) issues related to leather production. However, more work is required, in particular on the following topics: animal welfare stewardship practices; efficient local raw moderne. Îmbunătăţirile s-au desfăşurat, în principal, pentru a garanta compatibilitatea producţiei industriale cu cerinţele civice în comunităţile în care au fost prezente tăbăcăriile, însă devin din ce în ce mai importante ca instrument de marketing care vizează orientarea deciziilor de cumpărare ale consumatorilor. În special, în ultimii 50 de ani, tăbăcarii europeni au obţinut realizări de mediu uimitoare, prin cooperarea activă a tuturor actorilor din lanţul de aprovizionare tehnologică. Tăbăcăriile de astăzi consumă mai puţină apă, mai puţină energie şi au înlocuit produsele chimice periculoase. Tratează apele uzate în mod eficient, recuperează şi reciclează cea mai mare parte a deşeurilor organice. Dezvoltarea tehnologică avansată, combinată cu inovaţia în comunicarea de mediu şi armonizarea standardelor internaţionale privind amprenta produselor asupra mediului sunt necesare pentru a garanta dezvoltarea durabilă a tăbăcăriilor în general şi, în special, a celor din sectorul european. Unele dintre priorităţile cheie identificate sunt, prin urmare, legate de amprenta asupra mediului, cu tehnici de procesare şi cu tehnologii de depoluare la final de proces: identificarea metodologiilor adecvate şi armonizate cu privire la analiza ciclului de viaţă (LCA) - amprenta de carbon/apă; implementarea, după caz, a ecodesign-ului în cadrul întregului lant valoric al pielii; optimizarea consumului de apă şi gestiunea apelor reziduale; niveluri de eficienţă energetică îmbunătăţite; reducerea la minimum a deşeurilor prin reutilizarea şi reciclarea produselor secundare; standarde şi reglementări care să recompenseze performanţa de mediu.

\section{Social}

Sub aspectul pilonului social al sustenabilităţii, industria de pielărie are diferite implicaţii "specifice factorilor interesaţi", ceea ce duce la strategii de dezvoltare diferite. Comunităţile locale, ONG-urile sociale şi de mediu, muncitorii şi sindicatele lor, elevii, studenţii şi ucenicii sunt exemple de factori interesaţi care interacţionează cu tăbăcăriile şi pot avea un impact asupra dezvoltării lor. Atunci când tăbăcăriile sunt agregate în districte industriale (cum este cazul pentru majoritatea companiilor din sudul Europei), bunăstarea teritoriilor depinde în mare măsură de aceste tăbăcării. Experienţele recente legate de participarea mai multor factori interesaţi au demonstrat eficacitatea acestora în identificarea platformelor de dialog pentru a discuta aspectele sociale şi de mediu legate de producţia de piele. Cu toate acestea, sunt necesare mai multe eforturi, în special, în privinţa următoarelor teme: practici de 
material sourcing; image building and attractiveness of the sector to new generations; Corporate Social Responsibility branding; Skills development and the support of first class education and training at sector level.

\section{Acknowledgements}

COTANCE would like to thank ETUF:TCL / IndustriAll European Trade Union, its Social Partner and partner in this EU sponsored projects for the excellent cooperation throughout the initiative.

The Social partners of this project express their gratitude in particular to all European Leather Associations, companies and worker representatives that have offered their support and contribution to the development of all activities.

Finally, COTANCE and IndustriAll European Trade Union thank the European Commission and in particular the Directorate General for Social Affairs for the financial support received for the development of the 3 SER projects. asigurare a bunăstării animalelor; aprovizionare eficientă cu materii prime locale; îmbunătăţirea imaginii şi a atractivităţii sectorului pentru noile generaţii; responsabilitate socială corporatistă; dezvoltarea competenţelor şi sprijinirea educaţiei şi formării specializate la nivel de sector.

\section{Mulţumiri}

COTANCE doreşte să mulţumească ETUF:TCL / Federaţiei europene IndustriAll, partenerilor sociali şi partenerilor din acest proiect susţinut de UE pentru cooperarea excelentă pe tot parcursul acestei iniţiative.

Partenerii sociali ai acestui proiect îşi exprimă recunoştinţa faţă de toate Asociaţiile de Pielărie din Europa, firmele şi reprezentanţii angajaţilor care şi-au oferit sprijinul şi au contribuit la dezvoltarea tuturor activităţilor.

În cele din urmă, COTANCE şi Federaţia europeană IndustriAll mulţumesc Comisiei Europene şi în special Direcţiei Generale de Afaceri Sociale pentru sprijinul financiar acordat pentru dezvoltarea a 3 proiecte SER.

\section{REFERENCES}

1. COTANCE - Social Project (VS/2008/0478) and Follow-up Projects (VS/2009/0473 \& VS/2011/0407) "Social \& Environmental Reporting in the European Leather Industry", 2009-2012, Brussels.

2. Social \& Environmental Report- the European Leather Industry", 2012, Brussels.

3. http://www.euroleather.com/socialreporting

This paper has been elaborated with the support of the European Commission. The content is the sole responsibility of the authors and does not necessarily reflect the position of the European Commission.

Această lucrare a fost elaborată cu sprijinul Comisiei Europene. Această publicaţie reflectă doar punctele de vedere ale autorului, iar Comisia nu poate fi considerată responsabilă pentru utilizarea informaţiilor conţinute.

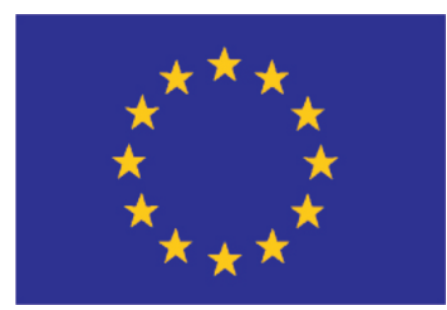

